\title{
The behavior of mixed-metal oxides: Physical and chemical properties of bulk $\mathrm{Ce}_{1-x} \mathrm{~Tb}_{x} \mathrm{O}_{2}$ and nanoparticles of $\mathrm{Ce}_{1-x} \mathrm{~Tb}_{x} \mathrm{O}_{y}$
}

\author{
Xianqin Wang, Jonathan C. Hanson, Gang Liu, and José A. Rodriguez ${ }^{\text {a) }}$ \\ Chemistry Department, Brookhaven National Laboratory, Building 555, Upton, New York 11973
}

Ana Iglesias-Juez and Marcos Fernández-García ${ }^{a)}$

Instituto de Catálisis y Petroleoquímica, CSIC, Campus Cantoblanco, 28049 Madrid, Spain

(Received 9 April 2004; accepted 17 June 2004)

\begin{abstract}
The physical and chemical properties of bulk $\mathrm{Ce}_{1-x} \mathrm{~Tb}_{x} \mathrm{O}_{2}$ and $\mathrm{Ce}_{1-x} \mathrm{~Tb}_{x} \mathrm{O}_{y}$ nanoparticles $(x$ $\leqslant 0.5$ ) were investigated using synchrotron-based x-ray diffraction (XRD), x-ray adsorption near edge spectroscopy (XANES), Raman spectroscopy (RS), and first-principles density-functional (DF) calculations. DF results and Raman spectra point to a small tetragonal distortion after introducing terbium in ceria. The results of XRD show a small contraction $(\leqslant 0.08 \AA)$ in the cell dimensions. The presence of $\mathrm{Tb}$ generates strain in the lattice through the variation of the ionic radii and creation of crystal imperfections and $\mathrm{O}$ vacancies. The strain increases with the content of $\mathrm{Tb}$ and affects the chemical reactivity of the $\mathrm{Ce}_{1-x} \mathrm{~Tb}_{x} \mathrm{O}_{y}$ nanoparticles towards hydrogen, $\mathrm{SO}_{2}$, and $\mathrm{NO}_{2}$. DF calculations for bulk $\mathrm{Ce}_{1-x} \mathrm{~Tb}_{x} \mathrm{O}_{2}$ and $\mathrm{Ce}_{8-} \mathrm{Tb}_{n} \mathrm{O}_{16}(n=0,1,2$, or 4$)$ clusters show oxide systems that are not fully ionic. The theoretical results and XANES spectra indicate that neither a $\mathrm{Ce} \leftrightarrow \mathrm{Tb}$ exchange nor the introduction of oxygen vacancies in $\mathrm{Ce}_{1-x} \mathrm{~Tb}_{x} \mathrm{O}_{y}$ significantly affect the charge on the $\mathrm{Ce}$ cations. In contrast, the $\mathrm{O} K$-edge and $\mathrm{Tb} L_{\mathrm{III}}$-edge XANES spectra for $\mathrm{Ce}_{1-x} \mathrm{~Tb}_{x} \mathrm{O}_{y}$ nanoparticles show substantial changes with respect to the corresponding spectra of $\mathrm{Ce}$ and $\mathrm{Tb}$ single oxide references. The $\mathrm{Ce}_{0.5} \mathrm{~Tb}_{0.5} \mathrm{O}_{y}$ compounds exhibit a much larger $\mathrm{Tb}^{3+} / \mathrm{Tb}^{4+}$ ratio than $\mathrm{TbO}_{1.7}$. A comparison with the properties of $\mathrm{Ce}_{1-x} \mathrm{Zr}_{x} \mathrm{O}_{y}$ and $\mathrm{Ce}_{1-x} \mathrm{Ca}_{x} \mathrm{O}_{y}$ shows important differences in the charge distribution, the magnitude of the dopant induced strain in the oxide lattice, and a superior behavior in the case of the $\mathrm{Ce}_{1-x} \mathrm{~Tb}_{x} \mathrm{O}_{y}$ systems. The Tb-containing oxides combine stability at high temperature against phase segregation and a reasonable concentration of $\mathrm{O}$ vacancies, making them attractive for chemical and catalytic applications. (c) 2004 American Institute of Physics. [DOI: 10.1063/1.1781116]
\end{abstract}

\section{INTRODUCTION}

Mixed-metal oxides play a very important role in many areas of chemistry, physics, and materials science. ${ }^{1,2}$ In general, there is a need to obtain a fundamental understanding of the phenomena associated with the behavior of these complex systems. In this paper, we investigate the physical and chemical properties of bulk $\mathrm{Ce}_{1-x} \mathrm{~Tb}_{x} \mathrm{O}_{2}$ and $\mathrm{Ce}_{1-x} \mathrm{~Tb}_{x} \mathrm{O}_{y}$ nanoparticles $(x \leqslant 0.5)$. Rare-earth oxides have been frequently used as structural and electronic promoters to improve the activity, selectivity, and thermal stability of metal catalysts. ${ }^{1-4} \mathrm{CeO}_{2}$, among the rare-earth oxides, is certainly the most widely used oxide in industrial catalysis, ${ }^{2}$ especially for the treatment of combustion emissions (oxidation of $\mathrm{CO}$, destruction of nitrogen and sulfur oxides). The emission of nitrogen and sulfur oxides $\left(\mathrm{NO}_{x}\right.$ and $\left.\mathrm{SO}_{x}\right)$ from fuel combustion in power stations, industrial heaters, and road transportation leads to a variety of environmental problems: the formation of acid rain and the resultant acidification of aquatic ecosystems, the generation of ozone ( $\mathrm{smog}$ ) in the troposphere, and respiratory health hazards for humans. Depending on the nature of the combustion process, various approaches for $\mathrm{NO}_{x}$ and $\mathrm{SO}_{x}$ removal have been

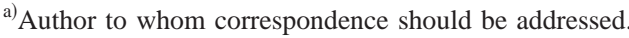

developed. ${ }^{1,3}$ Ceria or ceria-based materials have been reported to be good for improving the performance of catalysts employed for the destruction of nitrogen oxides $\left(\mathrm{DeNO}_{x}\right)^{5-7}$ due to their unique ability to combine oxygen storage and release by the shift between reduced $\mathrm{Ce}^{3+}$ and oxidized $\mathrm{Ce}^{4+}$ states. $^{8-10}$ The chemical and catalytic behavior of ceria and ceria-based materials in $\mathrm{DeNO}_{x}$ and $\mathrm{DeSO}_{x}$ processes have attracted a lot of attention. ${ }^{10-13}$ Studies with welldefined single-crystal surfaces have shown the important role that $\mathrm{O}$ vacancies and structural imperfections play in the cleavage of N-O and S-O bonds on ceria-based oxides. ${ }^{14}$

In many cases, the redox properties and chemical activity of pure ceria can be enhanced by introducing different types of metals $(\mathrm{Zr}, \mathrm{Ca}, \mathrm{Cu}, \mathrm{Tb}, \mathrm{Mn}$, etc.) into the oxide lattice. ${ }^{14-17}$ With respect to single-metal oxides, the chemical behavior of mixed-metal oxides may be different as a consequence of several factors. ${ }^{12}$ At a structural level, a dopant or second metal can introduce stress into the lattice of an oxide host, inducing in this way the formation of defects that have a high chemical activity. On the other hand, the lattice of the oxide host can impose on the dopant element nontypical coordination modes with a subsequent perturbation in the dopant chemical properties. Finally, metal $\leftrightarrow$ metal or metal $\leftrightarrow$ oxygen $\leftrightarrow$ metal interactions in mixed-metal oxides can lead to electronic properties not seen in single-metal 
oxides. ${ }^{12}$ Recently, the structural and electronic properties of oxide nanoparticle that combine $\mathrm{Ce}$ and $\mathrm{Zr}$ or $\mathrm{Ca}$ have been studied due to their potential uses in the field of catalysis. ${ }^{11(a)}$ $\mathrm{Zr}$ mixing $\left(\mathrm{Ce}_{1-x} \mathrm{Zr}_{x} \mathrm{O}_{2}\right)$ improved the thermal stability of ceria nanoparticles, but did not introduce a significant number of oxygen vacancies. ${ }^{18}$ On the other hand, Ca mixing $\left(\mathrm{Ce}_{1-x} \mathrm{Ca}_{x} \mathrm{O}_{y}\right)$ introduced a lot of oxygen vacancies in the host structure, which radically modify the chemical properties of the system and facilitate the destruction of $\mathrm{N}$ - and S-containing pollutants, ${ }^{11(a), 12,14}$ but the mixed-metal oxide had a relatively low stability and phase segregation into $\mathrm{CeO}_{2}$ and $\mathrm{CaO}$ was observed at temperatures close to $700{ }^{\circ} \mathrm{C} .{ }^{19}$ A priori, it is not clear what type of second metal is useful to improve both the stability at high temperature and the chemical activity, which as said above, is directly linked to the level of $\mathrm{O}$ vacancies in ceria. It is interesting to investigate the effects of a lanthanide like $\mathrm{Tb}$ on the properties of ceria-based oxides. $^{8,15(\mathrm{~b}), 20,21}$

$\mathrm{Ce}_{1-x} \mathrm{~Tb}_{x} \mathrm{O}_{y}$ compounds have been reported to have a superior performance in the storage or release of oxygen. ${ }^{8,20-23}$ It was proposed that the presence of $\mathrm{O}$ vacancies associated with $\mathrm{Tb}^{3+}$ contributed to enhance the oxygen mobility. ${ }^{24}$ In order to fully understand this phenomenon, we must know well the physical and chemical properties of the $\mathrm{Ce}_{1-x} \mathrm{~Tb}_{x} \mathrm{O}_{y}$ system and verify the existence of $\mathrm{Tb}^{3+}$ and the concomitant presence of $\mathrm{O}$ vacancies. In this work, firstprinciples density-functional (DF) calculations ${ }^{11,12}$ are used to investigate the structure and bonding in $\mathrm{Ce}-\mathrm{Tb}$ oxides (clusters and bulk compounds). The physical and chemical properties of $\mathrm{Ce}_{1-x} \mathrm{~Tb}_{x} \mathrm{O}_{y}$ nanoparticles are systematically investigated using synchrotron based time-resolved $\mathrm{x}$-ray diffraction, ${ }^{18,19}$ x-ray absorption near edge spectroscopy (XANES), ${ }^{11,18,19}$ and Raman spectroscopy. ${ }^{11,19}$ At the end, the results are compared with those obtained with the same techniques for the $\mathrm{Ce}_{1-x} \mathrm{Zr}_{x} \mathrm{O}_{2}$ and $\mathrm{Ce}_{1-x} \mathrm{Ca}_{x} \mathrm{O}_{y}$ systems. ${ }^{18,19}$ The Tb-containing oxides are special, showing distinctive structural and electronic properties that make them attractive for chemical and catalytic applications.

\section{EXPERIMENTAL AND THEORETICAL METHODS}

\section{A. Sample preparation}

Ceria and $\mathrm{Ce}_{1-x} \mathrm{~Tb}_{x} \mathrm{O}_{y}$ nanoparticles were synthesized with an adapted microemulsion method reported elsewhere. ${ }^{18,25,26}$ Three samples were prepared with different initial $\mathrm{Ce} / \mathrm{Tb}$ ratios of $9 / 1,2 / 1$, and $1 / 1$. These materials will be hereafter referred to as $\mathrm{Ce}_{0.9} \mathrm{~Tb}_{0.1} \mathrm{O}_{y}, \mathrm{Ce}_{0.66} \mathrm{~Tb}_{0.33} \mathrm{O}_{y}$, and $\mathrm{Ce}_{0.5} \mathrm{~Tb}_{0.5} \mathrm{O}_{y}$ (in correlation with the corresponding atomic ratios) and display Brunauer-Emmett-Teller (B.E.T.) surface areas $\left(S_{\mathrm{BET}}\right)$ of 121,94 , and $96 \mathrm{~m}^{2} \mathrm{~g}^{-1}$, respectively. $\mathrm{CeO}_{2}$ and $\mathrm{TbO}_{x}$ reference systems were prepared following the same methodology ${ }^{18,25,26}$ yielding solids with $S_{\text {BET }}$ of 122 and $14 \mathrm{~m}^{2} \mathrm{~g}^{-1}$, respectively.

\section{B. Time-resolved XRD experiments and data analysis}

The time resolved $\mathrm{x}$-ray diffraction experiments were carried out on beam line X7B of the National Synchrotron Light Source (NSLS) at Brookhaven National Laboratory. As in previous studies for other ceria-based compounds, ${ }^{18,19}$ we found no indication of beam induced damage on the $\mathrm{Ce}_{1-x} \mathrm{~Tb}_{x} \mathrm{O}_{y}$ samples. The temperature programmed sintering of the samples in air or reaction under a $5 \% \mathrm{H}_{2} / \mathrm{He}$ environment was investigated. Each sample was loaded into a sapphire capillary cell which was attached to a flow system. ${ }^{18,19,27,28}$ A small resistance heater was wrapped around the capillary, and the temperature was monitored with a $0.1 \mathrm{~mm}$ chromel-alumel thermocouple which was placed straight into the capillary near the sample. In the case of air environment, both sides of the sapphire cell were open to air, while they were connected to the gas lines for the $5 \% \mathrm{H}_{2} / \mathrm{He}$ environment. Diffraction patterns were collected in the temperature range of $25-925^{\circ} \mathrm{C}$ for sintering in air, and $25-$ $900{ }^{\circ} \mathrm{C}$ in the case of reduction with hydrogen. A MAR345 detector was used to record x-ray patterns. The data for oxygen occupancy determination were collected at the beamline 1-ID $(\lambda=0.1536 \AA)$ of $x$-ray Operation and Research in the Advance Photon Source (APS) at Argonne National Laboratory with the same setup as that at the NSLS. The data with a high-order wave vector $Q\left(\approx 11.5 \AA^{-1}\right)$ from the APS give a better determination of the structural parameters.

In this work, a whole profile refinement with the commercial Reflex package provided by Accelrys was employed to obtain the particle sizes, cell dimension, and lattice strain. Here lattice strain was determined from the variation of peak width, and is an estimation of the stress, produced by imperfections and defects, in the crystal structure. ${ }^{29(a)-29(e)}$ The data analysis consisted of several steps. First, the powder rings were integrated with the FIT2D (Ref. 30) code for each slice of the sample. The FIT2D parameters for the integration of the data were obtained from a standard $\mathrm{LaB}_{6}$ powder pattern, and were ascertained with a silicon powder pattern. Thereafter, the particle size, cell dimension, and strain in the lattice of samples were also obtained by a whole profile refinement with the commercial Reflex package provided by Accelrys. ${ }^{29(b)}$ The instrumental parameters were derived from the fit of a Si reference pattern using a Thompson-CoxHasting function profile, ${ }^{29(c)}$ and asymmetry correction of Berar-Baldinozzi function. ${ }^{29(\mathrm{~d})}$ These parameters were kept the same for the data refinement of all the samples. The variations of the cell dimension, particle sizes, strain, and other factors versus the temperature or time were thus obtained. The error bars for the cell dimension, particle sizes, and strain were found to be very small with maximum errors of $0.1 \%, 1 \%$, and $1.5 \%$, respectively. Hence, error bars are not displayed in the figures shown in Sec. III. Oxygen occupancies were determined by a Rietveld analysis with the general structure analysis system (GSAS) program $^{31}$ of the data collected at the APS.

\section{XANES experiments}

The Ce and $\mathrm{Tb} L_{\mathrm{III}}$-edge XANES spectra were collected at the NSLS on beam line X19A in the "fluorescence-yield mode" using a boomerang-type flat crystal monochromator and a modified Stern-Heald-Lytle detector. Beamline U7A was utilized to record the $\mathrm{O} K$-edge spectra. This beamline is equipped with a toroidal spherical grating monochromator. The $\mathrm{O} K$-edge spectra were taken in the "electron-yield mode" by using a channeltron multiplier located near the 
sample surface. The energy resolution at the $\mathrm{Ce}$ and $\mathrm{Tb}$ $L_{\mathrm{III}}$-edges and the $\mathrm{O} K$-edge was close to $0.5 \mathrm{eV}^{18}{ }^{18} \mathrm{In}$ our XANES experiments, we found no indication of beam damage. In tests measurements, spectra were taken very fast or drastically reducing the intensity of the beam, and these changes only affected the quality of the signal-to-noise ratio in the data without introducing new features.

\section{Raman experiments}

Raman spectra were obtained at room temperature with a Renishaw Dispersive system 1000, equipped with a cooled TCD and holographic Notch filter. The samples were excited with the $415 \mathrm{~nm} \mathrm{Ar}$ line and the spectra consisted of 50 accumulations with a total of $10-15$ min acquisition time, using a typical running power of $2-10 \mathrm{~mW}$. Care was taken in minimizing heating of the samples; peak positions were seen constant within $2-3 \mathrm{~cm}^{-1}$.

\section{E. Density functional calculations}

The first-principles calculations reported in Sec. III were performed using the CASTEP (Cambridge Serial Total Energy Package) suite of programs. ${ }^{32}$ In this code, the Kohn-Sham implementation of DF theory is used to obtain the total energy of the system. CASTEP has an excellent track record in accurate prediction of geometry and energetics for oxide systems. ${ }^{18,19,32(b), 33}$ The wave functions of valence electrons are expanded in a plane wave basis set with $k$ vectors within a specified energy cutoff $E_{\text {cut }}$. Tightly-bound core electrons are represented by nonlocal ultrasoft pseudopotentials. ${ }^{34}$ Brillouin zone integration is approximated by a sum over special $k$ points chosen using the Monkhorst-Pack scheme. ${ }^{35}$ In all the calculations, the kinetic energy cutoff $E_{\text {cut }}(400 \mathrm{eV})$ and the density of the Monkhorst-Pack $k$-point mesh (a $4 \times 4 \times 4$ grid in the smallest unit cells, reduced to a $4 \times 4 \times 2$ grid for larger cells) were chosen high enough in order to ensure convergence of the computed structures and energetics. The exchange-correlation contribution to the total electronic energy was treated in a generalized-gradient corrected (GGA) form of the local density approximation: Perdew-Burke-Ernzerhoff functional. ${ }^{36}$ The structural parameters of the $\mathrm{CeO}_{2}$ and $\mathrm{Ce}_{1-x} \mathrm{~Tb}_{x} \mathrm{O}_{2}$ systems in their different configurations were determined using the Broyden-FletcherGoldfarb-Shanno minimization technique, with the following thresholds for the converged structures: energy change per atom less than $5 \times 10^{-6} \mathrm{eV}$, residual force less than 0.02 $\mathrm{eV} / \AA$, the displacement of atoms during the geometry optimization less than $0.001 \AA$, and the rms of the stress tensor less than $0.1 \mathrm{GPa}$. For each optimized structure, the partial charges on the atoms were estimated by projecting the occupied one-electron eigenstates onto a localized basis set with a subsequent Mulliken population analysis. ${ }^{37}$ Mulliken charges have well known limitations, ${ }^{38}$ but are nevertheless useful as a qualitative tool to study trends in charge distribution. One of our main interests here is to compare the charge distribution in the $\mathrm{CeO}_{2}$ and $\mathrm{Ce}_{1-x} \mathrm{~Tb}_{x} \mathrm{O}_{2}$ systems.

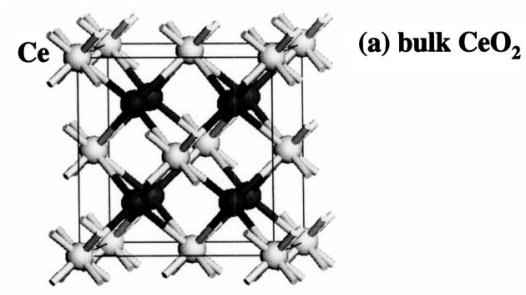

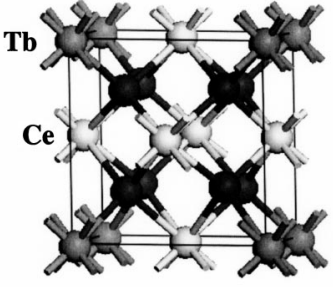

(b) bulk $\mathrm{Ce}_{0.75} \mathrm{~Tb}_{0.25} \mathrm{O}_{2}$

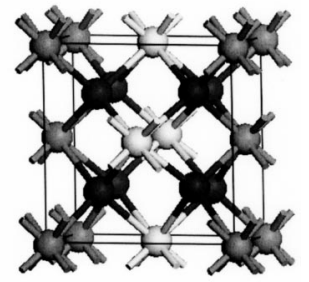

(c) bulk $\mathrm{Ce}_{0.5} \mathrm{~Tb}_{0.5} \mathrm{O}_{2}$

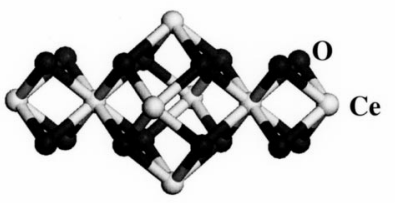

(d) $\mathrm{Ce}_{8} \mathrm{O}_{16}$ cluster

FIG. 1. Structures for bulk $\mathrm{CeO}_{2}$ (a), bulk $\mathrm{Ce}_{0.75} \mathrm{~Tb}_{0.25} \mathrm{O}_{2}$ (b), bulk $\mathrm{Ce}_{0.5} \mathrm{~Tb}_{0.5} \mathrm{O}_{2}$ (c), and a $\mathrm{Ce}_{8} \mathrm{O}_{16}$ cluster (d). Dark spheres represent the $\mathrm{O}$ atoms. The $\mathrm{Ce}$ and $\mathrm{Tb}$ atoms are represented by white and gray spheres, respectively.

\section{RESULTS AND DISCUSSIONS}

\section{A. Structural properties of the $\mathrm{Ce}_{1-x} \mathrm{~Tb}_{x} \mathrm{O}_{y}$ systems}

In the Periodic Table, Tb is in the same row as Ce (lanthanide series) and, thus, these elements have similar ionic and covalent radii. ${ }^{39}$ Furthermore, a fluorite-type crystal structure has been found for bulk $\mathrm{CeO}_{2}(a=5.41 \AA)$ (Ref. 18) and $\mathrm{TbO}_{2}(a \sim 5.2 \AA) .{ }^{40}$ Using DF calculations we investigated the structural properties of bulk $\mathrm{CeO}_{2}$, $\mathrm{Ce}_{0.75} \mathrm{~Tb}_{0.25} \mathrm{O}_{2}$, and $\mathrm{Ce}_{0.5} \mathrm{~Tb}_{0.5} \mathrm{O}_{2}$ as shown in Figs. 1(a)1(c). The calculations for bulk ceria gave a lattice constant of $5.46 \AA$, which is very close to that found in other theoretical studies ${ }^{14(\mathrm{a})}$ and in experiments $(5.41 \AA) .{ }^{18}$ For bulk $\mathrm{Ce}_{0.75} \mathrm{~Tb}_{0.25} \mathrm{O}_{2}$, the most stable structure exhibits a small tetragonal distortion $(a=b=5.42 \AA, c=5.44 \AA)$ with respect to the original $\mathrm{CeO}_{2}$ crystal. In the case of bulk $\mathrm{Ce}_{0.5} \mathrm{~Tb}_{0.5} \mathrm{O}_{2}$, again the most stable structure is pseudocubic $(a=b=5.38 \AA, c=5.40 \AA)$. The most important point here is that in a stoichiometric $\mathrm{CeO}_{2}$ lattice, the replacement of $\mathrm{Ce}$ by $\mathrm{Tb}$ produces a minor contraction in the cell dimensions $(\leqslant 0.08 \AA)$ and metal-oxygen distances. The same results were found in DF calculations for a series of $\mathrm{Ce}_{8} \mathrm{O}_{16}$ [Fig. 1(d)], $\mathrm{Ce}_{7} \mathrm{TbO}_{16}, \mathrm{Ce}_{6} \mathrm{~Tb}_{2} \mathrm{O}_{16}$, and $\mathrm{Ce}_{4} \mathrm{~Tb}_{4} \mathrm{O}_{16}$ clusters.

Figure 2 shows typical XRD data for $\mathrm{Ce}_{1-x} \mathrm{~Tb}_{x} \mathrm{O}_{y}$ nanoparticles at temperatures between 25 and $925^{\circ} \mathrm{C}$. The materials with different $\mathrm{Ce} / \mathrm{Tb}$ ratios investigated in this work are listed in the first column of Table I. Here, we will focus on the XRD results obtained at room temperature. The results for higher temperatures will be analyzed in Sec. III C. From 


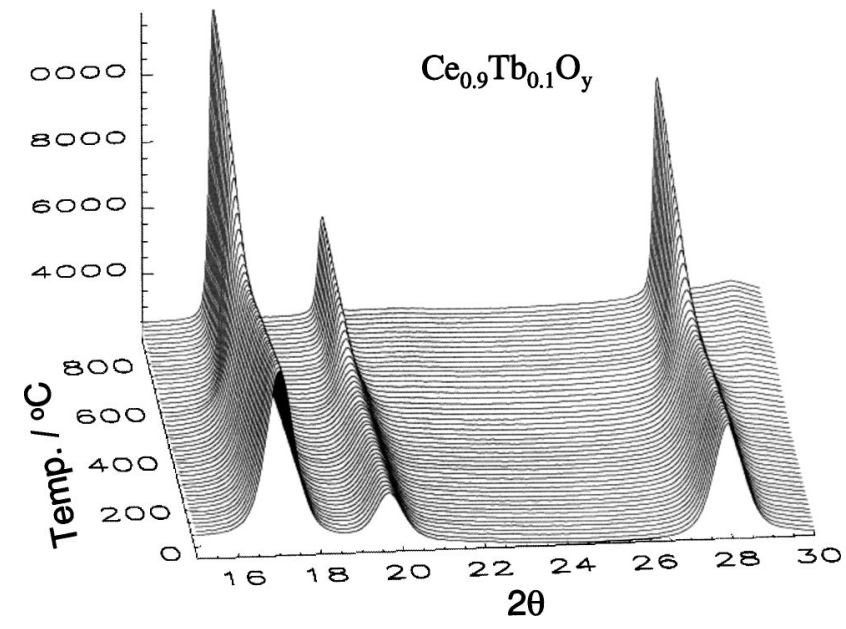

FIG. 2. Series of $\mathrm{x}$-ray diffraction patterns for the heating of $\mathrm{Ce}_{0.9} \mathrm{~Tb}_{0.1} \mathrm{O}_{y}$ in air. (Heating ramp $=4.8^{\circ} \mathrm{C} / \mathrm{min} ; \lambda=0.92007 \AA$ ).

the XRD patterns, one can get information ${ }^{11}$ about cell dimensions, particle sizes, lattice strain, and oxygen occupancies as shown in the columns of Table I. The reported particle sizes are consistent with particle sizes determined from TEM images, ${ }^{11}$ as already found for $\mathrm{Ce}-\mathrm{Zr}$ mixed oxides. ${ }^{5,11,18}$ The broad diffraction peaks associated with the nanoparticles do not allow to distinguish very small tetragonal distortions as predicted in the DF calculations for bulk $\mathrm{Ce}_{0.75} \mathrm{~Tb}_{0.25} \mathrm{O}_{2}$ and $\mathrm{Ce}_{0.5} \mathrm{~Tb}_{0.5} \mathrm{O}_{2}$. The cell parameters listed in Table I in some cases may represent an average value of a pseudocubic phase with a slight tetragonal distortion. Nevertheless, it is clear that $\mathrm{Ce}_{1-x} \mathrm{~Tb}_{x} \mathrm{O}_{y}$ nanoparticles have a smaller cell dimension than $\mathrm{CeO}_{2}$. (The same is valid for systems annealed to high temperature, as we will see in Sec. III C). In part this is a consequence of a $\mathrm{Ce} \leftrightarrow \mathrm{Tb}$ exchange in the oxide lattice. The $\mathrm{Ce}_{1-x} \mathrm{~Tb}_{x} \mathrm{O}_{y}$ nanoparticles have $\mathrm{O}$ vacancies when compared to $\mathrm{CeO}_{2}$. XRD can be used to determine the $\mathrm{O}$ occupancy in the lattice of regions within the $\mathrm{Ce}_{1-x} \mathrm{~Tb}_{x} \mathrm{O}_{y}$ nanoparticles that exhibit long-range order. ${ }^{11,19}$ The $\mathrm{O}$ occupancies determined from XRD point to $\mathrm{Ce}_{0.9} \mathrm{~Tb}_{0.1} \mathrm{O}_{1.94}, \mathrm{Ce}_{0.66} \mathrm{~Tb}_{0.33} \mathrm{O}_{1.84}$, and $\mathrm{Ce}_{0.5} \mathrm{~Tb}_{0.5} \mathrm{O}_{1.76}$ stoichiometries. The larger the content of terbium in $\mathrm{Ce}_{1-x} \mathrm{~Tb}_{x} \mathrm{O}_{y}$, the higher the number of $\mathrm{O}$ vacancies (i.e., the smaller the $\mathrm{O}$ occupancy). On the other hand, a rough constant number of $\mathrm{O}$ vacancies per $\mathrm{Tb}$ atom is detected for the $\mathrm{Ce}_{0.9} \mathrm{~Tb}_{0.1} \mathrm{O}_{1.94}, \mathrm{Ce}_{0.66} \mathrm{~Tb}_{0.33} \mathrm{O}_{1.84}$, and $\mathrm{Ce}_{0.5} \mathrm{~Tb}_{0.5} \mathrm{O}_{1.76}$ stoichiometries $(0.60,0.52$, and 0.48 , respectively). This would point out to a similar mechanism of vacancy creation in all the $\mathrm{Ce}-\mathrm{Tb}$ oxide samples.

TABLE I. Structural parameters for $\mathrm{Ce}_{1-x} \mathrm{~Tb}_{x} \mathrm{O}_{y}$ nanoparticles at room temperature.

\begin{tabular}{ccccc}
\hline \hline Ce/Tb ratio & $\begin{array}{c}\text { Cell } \\
\text { dimensions }(\AA)\end{array}$ & $\begin{array}{c}\text { Particle sizes } \\
(\mathrm{nm})\end{array}$ & $\begin{array}{c}\text { Strain } \\
(\text { a.u. })\end{array}$ & $\begin{array}{c}\text { Oxygen } \\
\text { occupancy }(\%)\end{array}$ \\
\hline $1 / 0$ & 5.40 & 6.7 & 0.92 & 100 \\
$9 / 1$ & 5.38 & 5.3 & 1.11 & 97 \\
$2 / 1$ & 5.36 & 5.1 & 1.16 & 92 \\
$1 / 1$ & 5.34 & 5.5 & 1.36 & 88 \\
\hline \hline
\end{tabular}

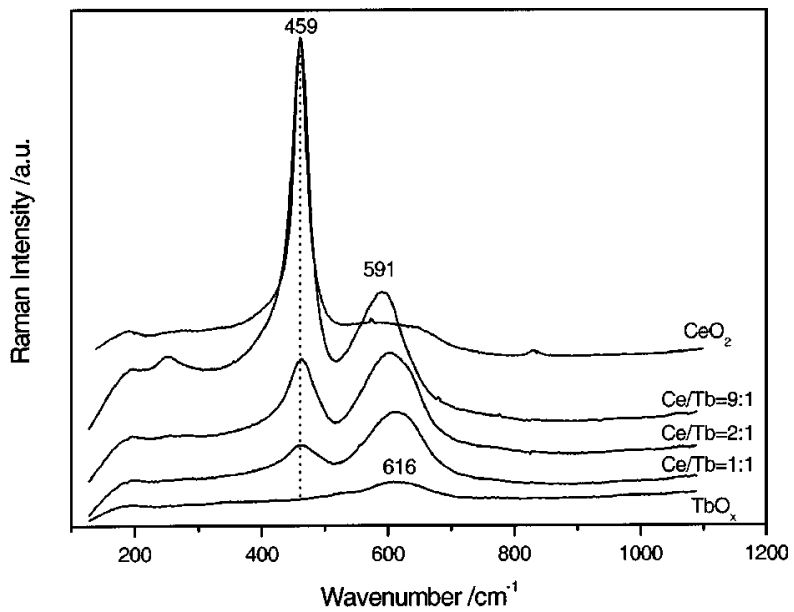

FIG. 3. Raman spectra for a series of Tb-containing ceria nanoparticles, and the references of $\mathrm{CeO}_{2}$ and $\mathrm{TbO}_{1.7}$.

Raman spectroscopy can be useful to detect oxygen sublattice distortions and the existence of $\mathrm{O}$ vacancies in ceriabased materials. ${ }^{11}$ Raman spectra for a series of $\mathrm{Tb}$ containing ceria nanoparticles and reference compounds, $\mathrm{CeO}_{2}$ and $\mathrm{TbO}_{1.7}$ (stoichiometric $\mathrm{TbO}_{2}$ is very difficult to prepare), ${ }^{40}$ are shown in Fig. 3. In general, two main features were seen at a low wave number of $459 \mathrm{~cm}^{-1}$ and a high wave number of around $600 \mathrm{~cm}^{-1}$. The shape of the $\mathrm{CeO}_{2}$ spectrum, with bands at 459 ( $F_{2 \mathrm{~g}}$ mode) and $\sim 825 \mathrm{~cm}^{-1}$ (second-order peak) as well as a broad feature centered around $550 \mathrm{~cm}^{-1}$ and associated with the presence of some oxygen vacancies, is fully consisted with previous reports of nanostructured ceria oxides. ${ }^{41}$ The presence of $\mathrm{Tb}$ decreases the main band intensity and induces the appearance of two weak peaks at $\sim 200$ and $250 \mathrm{~cm}^{-1}$ and an intense one at $591 \mathrm{~cm}^{-1}$. While the presence of four bands can be characteristic of a tetragonally distorted anion sublattice, ${ }^{18}$ the weakening of the low frequency bands with increasing $\mathrm{Tb}$ content in parallel with the main $F_{2 \mathrm{~g}}$ mode, could in fact indicate that these two minor peaks can be associated with enhanced second-order (transverse acoustic) modes typical of nanostructured fluorite-type structures. ${ }^{11}$ The decreasing intensity of these bands corresponds to a physical phenomenon and not to a different probability of photon absorption due to a change of color in the $\mathrm{Ce}-\mathrm{Tb}$ oxide series. This was demonstrated by using an IR excitation laser (results not shown). The broad band at $616 \mathrm{~cm}^{-1}$ is possibly associated with a first-order peak of the Tb-containing $\left(\mathrm{TbO}_{1.7}\right)$ material with fluoriterelated structure, and was also detected with significant intensity using red instead of green excitation. The broad nature of such peak is shared by the $\mathrm{TbO}_{1.7}$ reference and the $\mathrm{Ce}-\mathrm{Tb}$ mixed oxides. This could be a consequence of either an ordering effect in the oxygen vacancies as to produce confinement of the phonons within a nonhomogeneous distribution of domains or structural distortions of the $\mathrm{O}$ sublattice, ${ }^{11}$ among which the tetragonal one predicted by the DFT results is the most simple one. Irrespective of the physical cause, the Raman spectra indicate that the presence of $\mathrm{Tb}$ in the ceria-fluorite structure exerts significant influence in the anion sublattice. 
TABLE II. Calculated Mulliken charges for bulk $\mathrm{CeO}_{2}$ and $\mathrm{Ce}_{0.75} \mathrm{M}_{0.25} \mathrm{O}_{2}$ $(\mathrm{e})^{\mathrm{a}}$

\begin{tabular}{cccc}
\hline \hline Compound & $\mathrm{q}(\mathrm{Ce})$ & $\mathrm{q}(\mathrm{M})$ & $\mathrm{q}(\mathrm{O})$ \\
\hline $\mathrm{CeO}_{2}$ & 1.42 & $\ldots$ & -0.71 \\
$\mathrm{Ce}_{0.75} \mathrm{~Tb}_{0.25} \mathrm{O}_{2}$ & 1.43 & 1.47 & -0.72 \\
$\mathrm{Ce}_{0.75} \mathrm{Zr}_{0.25} \mathrm{O}_{2}{ }^{\mathrm{b}}$ & 1.49 & 1.33 & -0.73 \\
$\mathrm{Ce}_{0.75} \mathrm{Ca}_{0.25} \mathrm{O}_{2}{ }^{\mathrm{c}}$ & 1.32 & 1.83 & -0.72 \\
\hline \hline
\end{tabular}

${ }^{\mathrm{a}} \mathrm{M}=\mathrm{Tb}, \mathrm{Zr}$, or $\mathrm{Ca}$.

${ }^{\mathrm{b}}$ From Ref. 18.

${ }^{c}$ From Ref. 19.

The strain in the $\mathrm{Ce}_{1-x} \mathrm{~Tb}_{x} \mathrm{O}_{y}$, nanoparticles as a function of Tb content is shown in Table I. Under ideal circumstances the Bragg peaks in a powder diffractogram should appear as narrow well-defined symmetrical peaks. There are a number of sources of distortion that can result in significant peak broadening and asymmetry. The three main contributions to the line shape include instrumental broadening, crystalline size broadening, and strain broadening. Strain is a measurement of the lattice stress existing in the materials because of the crystal imperfections: $O$ vacancies, other point defects, line defects, and plane defects. ${ }^{42}$ Pure ceria nanoparticles exhibit a lattice strain when compared to bulk $\mathrm{CeO}_{2}$. Clearly, the introduction of an alien species like $\mathrm{Tb}$ leads to extra forces that increase the strain in the lattice of the nanoparticles. In Table I, there is a qualitative correlation between the magnitude of the strain and the oxygen occupancy. The introduction of an $\mathrm{O}$ vacancy generates stress in the lattice of an oxide, ${ }^{19,42}$ but there are other important defect contributions to the strain that can be eliminated by annealing at high temperature as we will see in Sec. III C. Results to be presented below for the reaction of hydrogen with the $\mathrm{Ce}_{1-x} \mathrm{~Tb}_{x} \mathrm{O}_{y}$ systems suggest that the defects which contribute to the strain may have a direct impact on the chemical reactivity of the nanoparticles: the larger the strain, the easier the reduction of the mixed-metal oxides.

\section{B. Electronic properties of the $\mathrm{Ce}_{1-x} \mathrm{~Tb}_{x} \mathrm{O}_{y}$ systems}

Experimental and theoretical studies indicate that bulk $\mathrm{CeO}_{2}$ is not a fully ionic oxide. ${ }^{43,44}$ Experiments of photoelectron spectroscopies and optical reflectivity measurements show a strong hybridization of the metal and oxygen orbitals, ${ }^{43}$ and the valence band, although dominated by $\mathrm{O}$ $2 p$ character, still contains a significant amount of metal character. ${ }^{18,44}$ Thus, the charge on the metal cations is probably much smaller than the formal value of " +4 " frequently assigned, ${ }^{18,44}$ and $\mathrm{CeO}_{2}$ is best described as an ionocovalent compound or covalent insulator. ${ }^{18,43(\mathrm{c})}$ Our DF calculations for bulk $\mathrm{Ce}_{0.75} \mathrm{~Tb}_{0.25} \mathrm{O}_{2}$ and $\mathrm{Ce}_{0.5} \mathrm{~Tb}_{0.5} \mathrm{O}_{2}$, and for a series of $\mathrm{Ce}_{8-n} \mathrm{~Tb}_{n} \mathrm{O}_{16}(n=0,1,2$, or 4$)$ clusters, show systems that are not fully ionic.

Table II compares Mulliken charges calculated for bulk $\mathrm{CeO}_{2}, \quad \mathrm{Ce}_{0.75} \mathrm{~Tb}_{0.25} \mathrm{O}_{2}, \quad \mathrm{Ce}_{0.75} \mathrm{Zr}_{0.25} \mathrm{O}_{2}, \quad$ (Ref. 18) and $\mathrm{Ce}_{0.75} \mathrm{Ca}_{0.25} \mathrm{O}_{2} \cdot{ }^{19}$ In the $\mathrm{Ce}_{0.75} \mathrm{Zr}_{0.25} \mathrm{O}_{2}$ system there is an important contraction of the cell parameters $(\sim 0.07 \AA)$ with respect to $\mathrm{CeO}_{2}$ that leads to a reduction in the $\mathrm{Ce}-\mathrm{O}$ distances and an increase in the positive charge of Ce. ${ }^{18}$ For $\mathrm{Ce}_{0.75} \mathrm{~Tb}_{0.25} \mathrm{O}_{2}$, the variations in the cell parameters with re-

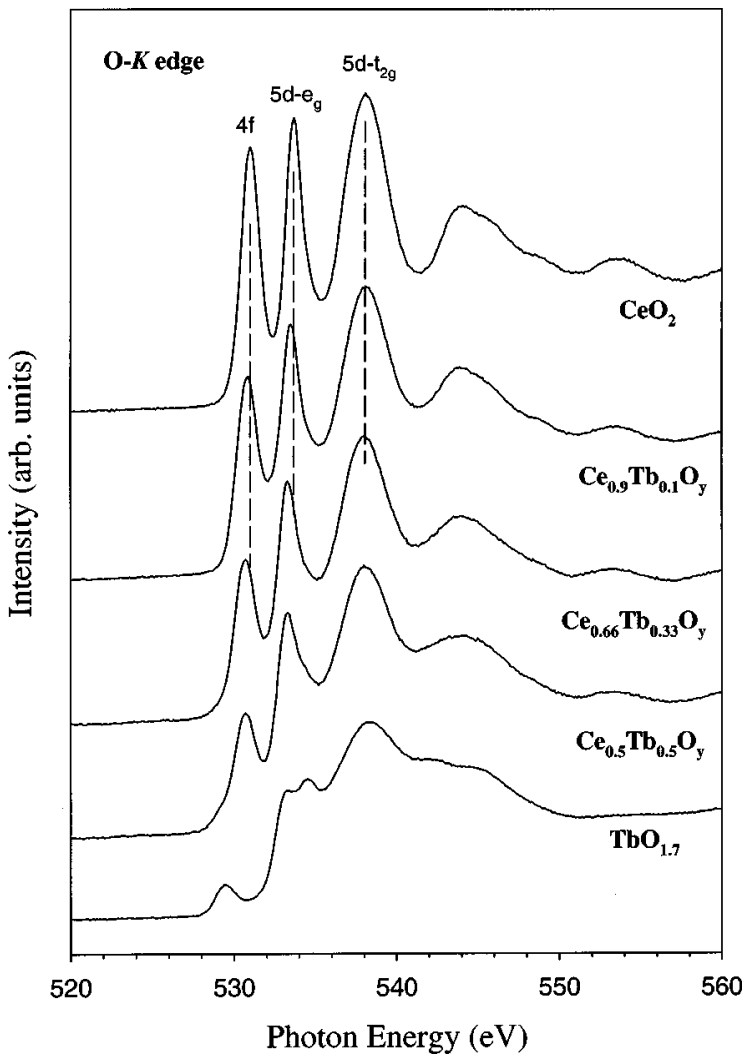

FIG. 4. O $K$-edge XANES spectra for $\mathrm{TbO}_{1.7}, \mathrm{CeO}_{2}$, and $\mathrm{Ce}_{1-x} \mathrm{~Tb}_{x} \mathrm{O}_{y}$ nanoparticles. The spectra were all recorded at $25^{\circ} \mathrm{C}$ in the electron-yield mode.

spect to $\mathrm{CeO}_{2}$ are relatively minor $(\sim 0.03 \AA)$ and there is a very small increase in the positive charge of $\mathrm{Ce}$ due to a slight shortening of the $\mathrm{Ce}-\mathrm{O}$ distances. In general, the density-functional calculations for bulk $\mathrm{Ce}_{1-x} \mathrm{~Tb}_{x} \mathrm{O}_{2} \quad(x$ $=0.25$ or 0.5$)$ and $\mathrm{Ce}_{8-n} \mathrm{~Tb}_{n} \mathrm{O}_{16}(n=0,1,2$, or 4$)$ clusters indicate that a $\mathrm{Ce} \leftrightarrow \mathrm{Tb}$ exchange slightly $(<0.05 e)$ increases the positive charge on the remaining $\mathrm{Ce}$ atoms. A large decrease for the Ce charge is seen in the case of bulk $\mathrm{Ce}_{0.75} \mathrm{Ca}_{0.25} \mathrm{O}_{2} \cdot{ }^{19}$ The $\mathrm{Ce}_{1-x} \mathrm{Ca}_{x} \mathrm{O}_{2}$ systems obey the Barr model for charge redistribution in mixed-metal oxides. ${ }^{12,19}$ The $\mathrm{Ca}$ atoms in $\mathrm{Ce}_{1-x} \mathrm{Ca}_{x} \mathrm{O}_{2}$ are more electropositive than the cations in $\mathrm{CaO}$, while the $\mathrm{Ce}$ cations of $\mathrm{Ce}_{1-x} \mathrm{Ca}_{x} \mathrm{O}_{2}$ are less electropositive than those of $\mathrm{CeO}_{2} \cdot{ }^{19}$ Different scales of electronegativity indicate that calcium is a much more electropositive element than $\mathrm{Tb}$ or $\mathrm{Zr}^{45}$ and $\mathrm{CaO}$ is a highly ionic compound. ${ }^{15(\mathrm{~d}), 19}$

The properties of the Tb-containing ceria nanoparticles, $\mathrm{CeO}_{2}$ and $\mathrm{TbO}_{1.7}$ were characterized with room temperature XANES at the $\mathrm{O} K$-, $\mathrm{Ce} L_{\mathrm{III}^{-}}$and Tb $L_{\mathrm{III}}$-edges. In Fig. 4, the $\mathrm{O} K$-edge spectrum of $\mathrm{CeO}_{2}$ showed three sharp peaks labeled as $4 f, 5 d-e_{\mathrm{g}}$ and $5 d-t_{2 \mathrm{~g}}$ at around $530.7 \mathrm{eV}, 533.5 \mathrm{eV}$, and $537.9 \mathrm{eV}$ respectively, as reported. ${ }^{46}$ Their presence is associated with the existence of unoccupied states made of $\mathrm{O}$ $2 p$ orbitals mixed with $\mathrm{Ce} 4 f$ and Ce $5 d$ orbitals. The $4 f$ peak is ideally suited for detecting the presence of $\mathrm{Ce}^{4+} \cdot{ }^{43(\mathrm{~b}), 47} \mathrm{TbO}_{1.7}$ showed several distinct features and the $\mathrm{Tb}$ containing samples did not have the same pattern, but shared a clear similarity with the spectrum for the pure $\mathrm{CeO}_{2}$ 


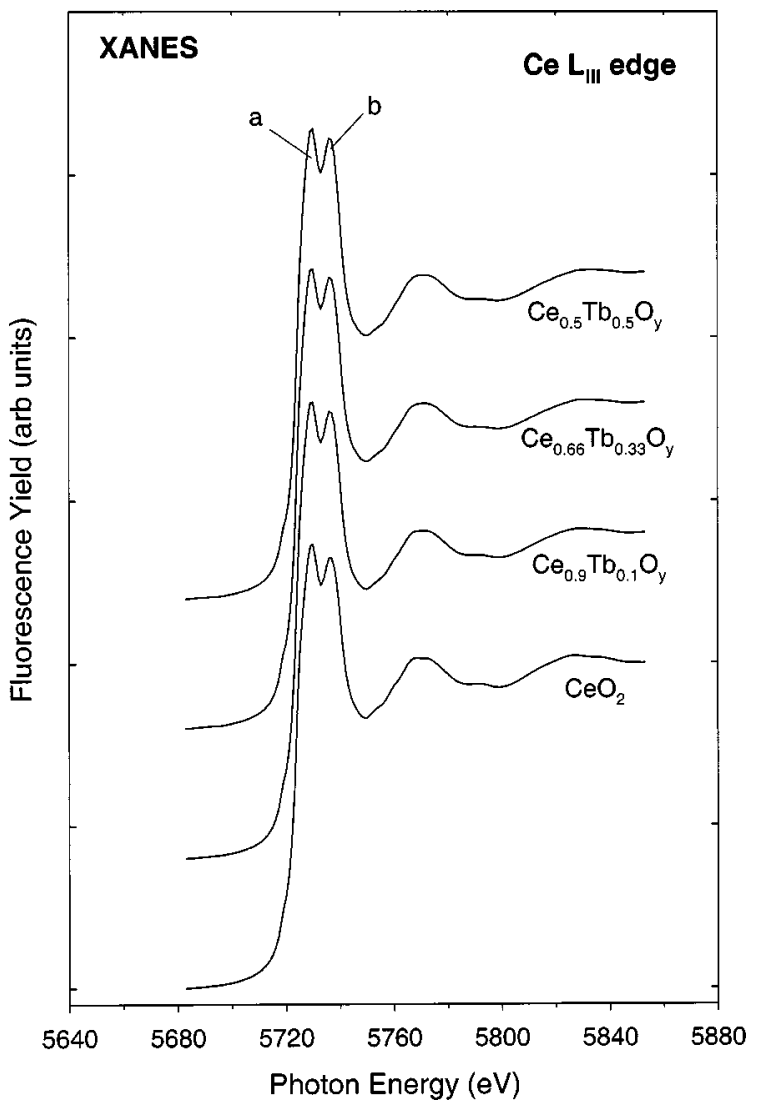

FIG. 5. Ce $L_{\mathrm{III}}$-edge XANES spectra for $\mathrm{CeO}_{2}$ reference and $\mathrm{Ce}_{1-x} \mathrm{~Tb}_{x} \mathrm{O}_{y}$ nanoparticles. The spectra were all recorded at $25^{\circ} \mathrm{C}$ in the fluorescenceyield mode.

sample. The relative intensity of the $4 f$ peak decreased with the increase of the $\mathrm{Tb}$ concentration indicating the presence of $\mathrm{O}$ near $\mathrm{Tb}$ atoms, with a weaker $\mathrm{Tb}-4 f / \mathrm{O}-2 p$ hybridization by effect of the shorter radius of the $\mathrm{Tb} 4 f$ as well as the $\mathrm{Tb} 4 f$ partial occupation. ${ }^{48}$ An additional effect comes from the smaller oxygen concentration around $\mathrm{Tb}$ originated by the presence of $\mathrm{Tb}^{3+}$ and associated oxygen vacancies with respect to $\mathrm{TbO}_{2}$. As indicated in Table I, the oxygen occupancy of the $\mathrm{Ce}_{0.5} \mathrm{~Tb}_{0.5} \mathrm{O}_{y}$ sample was $12 \%$ smaller than that of the pure nano ceria. The positions for the three main peaks displayed in Fig. 4 shifted simultaneously to lower photon energy with the increase of the $\mathrm{Tb}$ amount in the materials. The ionic Madelung field in the materials was probably altered by the $\mathrm{Tb}$ cations and concomitant shortening of bond distances. This was also detected in the $\mathrm{Ce}-\mathrm{Zr}$ and $\mathrm{Ce}-\mathrm{Ca}$ mixed oxide systems. ${ }^{18,19}$

Ce $L_{\mathrm{III}}$-edge XANES spectra for $\mathrm{CeO}_{2}$ and $\mathrm{Tb}$ containing ceria nanoparticles are presented in Fig. 5. Two main components " $a$ " and " $b$ " separated by around $7 \mathrm{eV}$ were observed for the oxide samples, in agreement with previous results, ${ }^{19,49}$ corresponding to two final state configurations, described as $\left[{ }^{*}\right] 4 f^{1} L^{n-1} 5 d^{1}$ and $\left[{ }^{*}\right] 4 f^{0} L^{n} 5 d^{1}$, respectively. The spectra for the nanoparticles were almost the same as that for $\mathrm{CeO}_{2}$, demonstrating the similar local structure and full oxidized state of $\mathrm{Ce}$ in the mixed-metal oxide nanoparticles. Neither the $\mathrm{Ce} \leftrightarrow \mathrm{Tb}$ exchange nor the $\mathrm{O}$ vacancies in $\mathrm{Ce}_{1-x} \mathrm{~Tb}_{x} \mathrm{O}_{y}$ significantly affect the charge on Ce.

$\mathrm{Tb} L_{\mathrm{III}}$-edge spectra of the $\mathrm{TbO}_{1.7}$ reference (stoichio-

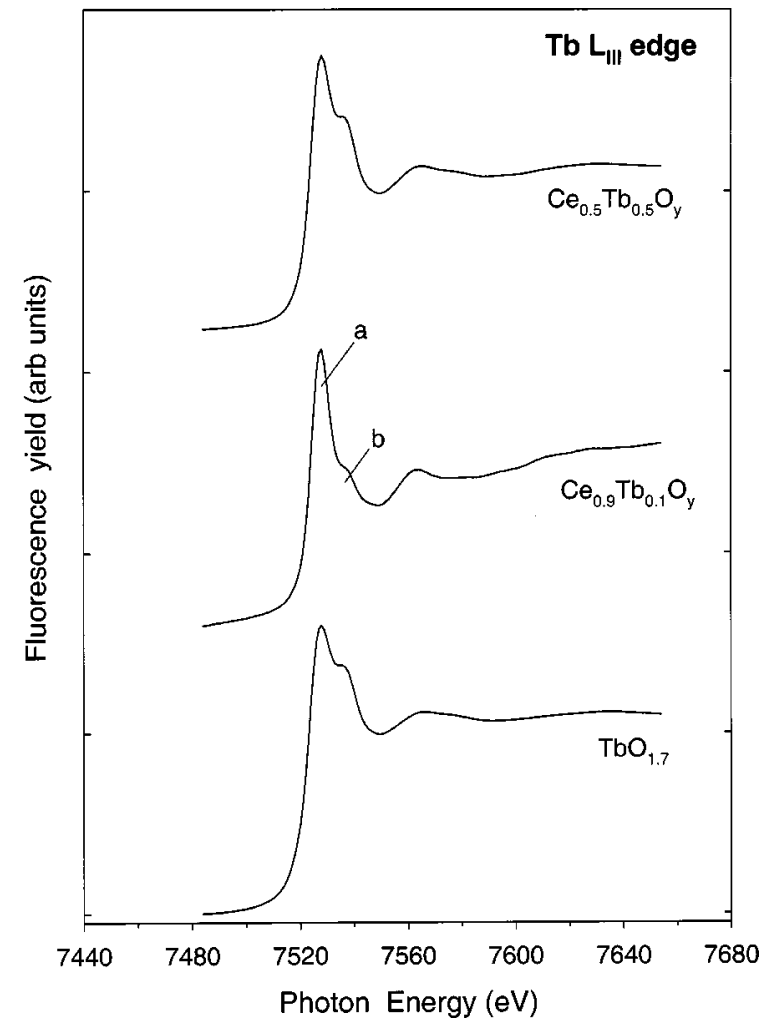

FIG. 6. Tb $L_{\mathrm{III}}$-edge XANES spectra for a $\mathrm{TbO}_{1.7}$ reference, $\mathrm{Ce}_{0.9} \mathrm{~Tb}_{0.1} \mathrm{O}_{y}$ and $\mathrm{Ce}_{0.5} \mathrm{~Tb}_{0.5} \mathrm{O}_{y}$ nanoparticles. The spectra were all recorded at $25^{\circ} \mathrm{C}$ in the fluorescence-yield mode.

metric $\mathrm{TbO}_{2}$ is very difficult to prepare $)^{40}$ and two mixedmetal oxides $\left(\mathrm{Ce}_{0.5} \mathrm{~Tb}_{0.5} \mathrm{O}_{y}, \mathrm{Ce}_{0.9} \mathrm{~Tb}_{0.1} \mathrm{O}_{y}\right)$ are displayed in Fig. 6. The Tb oxide reference spectrum is very close to that reported for a $\mathrm{Tb}_{4} \mathrm{O}_{7}$ phase. ${ }^{50}$ Two intense components, $a$ and $b$, and a weak one at higher energy were clearly evident in all the spectra of the samples. However, the relative intensity of the features $a$ and $b$, or their intensity ratio $(a / b)$, substantially changed. Feature $a$ gains intensity, while feature $b$ becomes much weaker when the concentration of $\mathrm{Ce}$ in the materials increases. This points to a change in the electronic properties of the terbium. In the $\mathrm{Ce}_{0.9} \mathrm{~Tb}_{0.1} \mathrm{O}_{y}$ sample, the average formal oxidation state is rather close to $\mathrm{Tb}^{3+}$, displaying a dominant single XANES feature in the white line region, characteristic of this reduced state. ${ }^{51}$ The presence of $\mathrm{Tb}^{3+}$ in $\mathrm{Ce}_{0.9} \mathrm{~Tb}_{0.1} \mathrm{O}_{y}$ is a consequence of the existence of oxygen vacancies and the need to fulfill charge neutrality since the formal oxidation state of cerium remains $+4{ }^{52}$ In the spectrum for the $\mathrm{Ce}_{0.5} \mathrm{~Tb}_{0.5} \mathrm{O}_{y}$ sample the magnitude of the $a / b$ intensity ratio is not as large as for the $\mathrm{Ce}_{0.9} \mathrm{~Tb}_{0.1} \mathrm{O}_{y}$ sample, but in $\mathrm{Ce}_{0.5} \mathrm{~Tb}_{0.5} \mathrm{O}_{y}$ it appears that the $\mathrm{Tb}^{3+} / \mathrm{Tb}^{4+}$ ratio is still substantially bigger than in $\mathrm{TbO}_{1.7}$ or $\mathrm{Tb}_{4} \mathrm{O}_{7} .{ }^{50}$ According to the XRD results in Table I, the number of $\mathrm{O}$ vacancies per $\mathrm{Tb}$ atom in $\mathrm{Ce}_{0.9} \mathrm{~Tb}_{0.1} \mathrm{O}_{y}(0.6)$ is larger than in $\mathrm{Ce}_{0.5} \mathrm{~Tb}_{0.5} \mathrm{O}_{y}(0.48)$. In principle, XANES should be sensitive to the effects of $\mathrm{O}$ atoms that are in amorphous regions of the nanoparticles and would not be detected in XRD measurements. ${ }^{11}$ The XANES data corroborate that the number of $\mathrm{O}$ vacancies per $\mathrm{Tb}$ atom decreases when going from $\mathrm{Ce}_{0.9} \mathrm{~Tb}_{0.1} \mathrm{O}_{y}$ to $\mathrm{Ce}_{0.5} \mathrm{~Tb}_{0.5} \mathrm{O}_{y}$. 

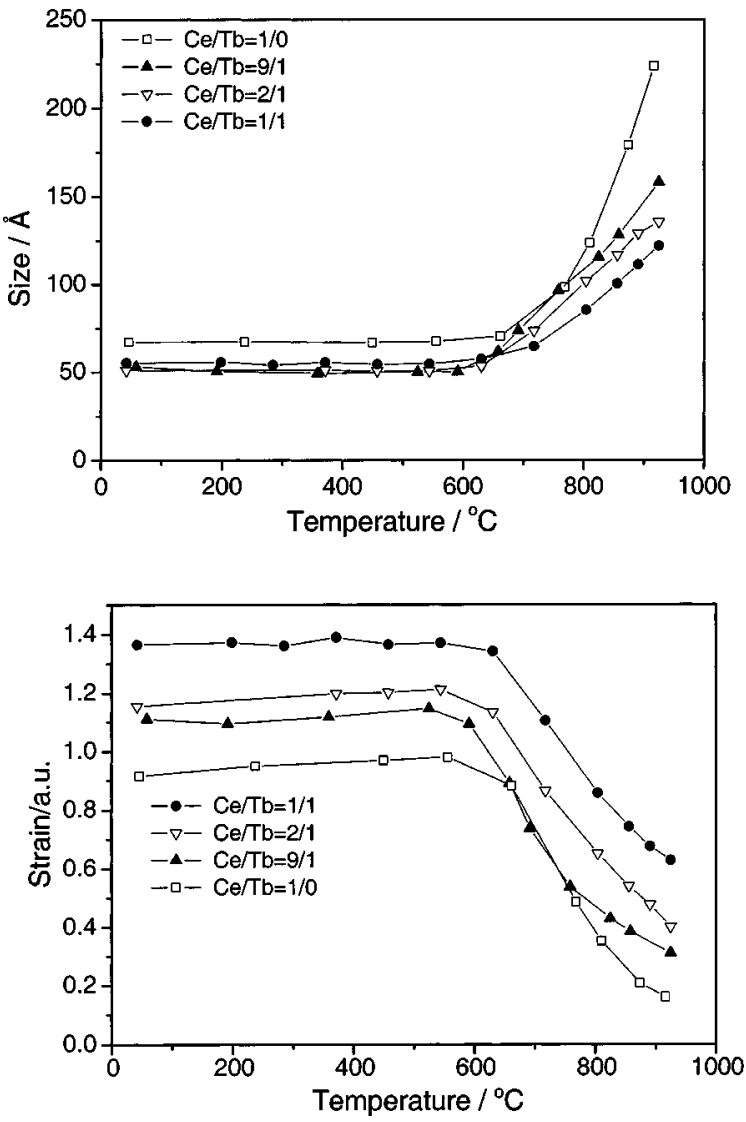

FIG. 7. Effects of temperature on the particle size (top panel) and lattice strain (bottom panel) of the $\mathrm{Ce}_{1-x} \mathrm{~Tb}_{x} \mathrm{O}_{y}$ systems.

\section{Effects of high temperature and sintering of $\mathrm{Ce}_{1-x} \mathrm{~Tb}_{x} \mathrm{O}_{y}$ nanoparticles}

Figure 2 shows temperature-resolved $\mathrm{x}$-ray diffraction patterns for the heating of $\mathrm{Ce}_{0.9} \mathrm{~Tb}_{0.1} \mathrm{O}_{y}$ nanoparticles from 25 to $925^{\circ} \mathrm{C}$ in air. Samples for $\mathrm{Ce}_{0.66} \mathrm{~Tb}_{0.33} \mathrm{O}_{y}$ and $\mathrm{Ce}_{0.5} \mathrm{~Tb}_{0.5} \mathrm{O}_{y}$ were studied in the same way and showed similar patterns. The intensity of the diffraction peaks gradually increased, and the peaks became sharper and narrower with the increase of temperature, indicating particle agglomeration at high temperature. ${ }^{11,18,52}$ No phase change was perceived for all of the Tb-containing ceria samples studied. Compared to $\mathrm{Ce}_{0.66} \mathrm{Ca}_{0.33} \mathrm{O}_{y}$ samples that underwent phase segregation when the temperature was raised close to $700{ }^{\circ} \mathrm{C},{ }^{19}$ the $\mathrm{Tb}$-containing ceria nanoparticles were very stable during the sintering process. This result proves that $\mathrm{TbO}_{y}$ is particularly suitable for making solid solutions with ceria possibly because its structure is of the cubic fluorite type and the $\mathrm{Tb}^{4+}(0.88 \AA)$ ionic radius is close enough to that of $\mathrm{Ce}^{4+}(0.97 \AA){ }^{4,51}$ The atomic radii of $\mathrm{Ce}(1.82 \AA)$ and $\mathrm{Tb}(1.78 \AA)$ are also similar. ${ }^{39}$

The top panel in Fig. 7 shows the effects of temperature on the particle sizes of the $\mathrm{Ce}_{1-x} \mathrm{~Tb}_{x} \mathrm{O}_{y}$ samples. The particle sizes were refined from TR-XRD data using a whole profile method. For $\mathrm{CeO}_{2}$, the particle size determined with XRD at room temperature $(\sim 7 \mathrm{~nm})$ agrees with that obtained from TEM images, ${ }^{52}$ and in studies that use different preparation methods. ${ }^{11,41}$ Compared to that of the pure nano ceria, the sizes for all the Tb-containing ceria nanoparticles were

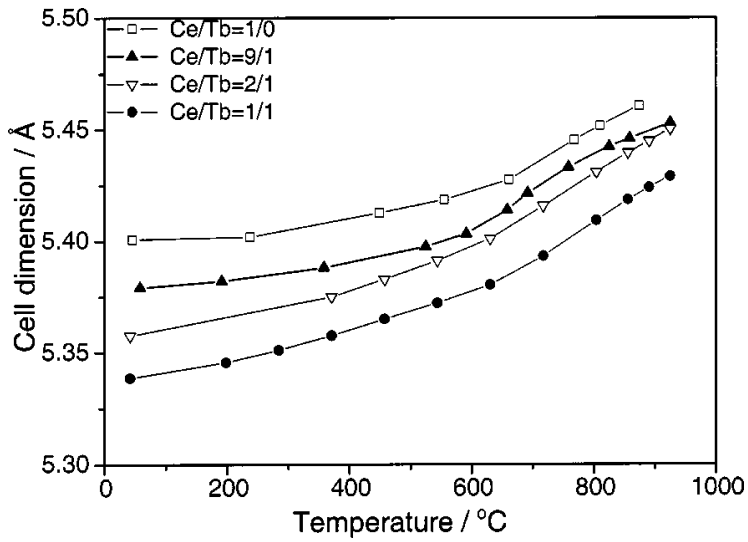

FIG. 8. Cell dimensions, as a function of temperature, for the $\mathrm{Ce}_{1-x} \mathrm{~Tb}_{x} \mathrm{O}_{y}$ nanoparticles.

around $5 \mathrm{~nm}$ at temperatures below $600^{\circ} \mathrm{C}$. At temperatures above $600{ }^{\circ} \mathrm{C}$, there is sintering and the particle size rises. The amount of sintering decreased with the increase of the $\mathrm{Tb}$ concentration in the samples. Thus, terbium seems to enhance the morphological stability of ceria nanoparticles at high temperature. In the bottom panel of Fig. 7, one can see the effects of temperature on the strain present in the lattice of the $\mathrm{Ce}_{1-x} \mathrm{~Tb}_{x} \mathrm{O}_{y}$ systems. During the sintering process defects and imperfections are removed from the lattice of the $\mathrm{Ce}-\mathrm{Tb}$ oxides and there is a very large drop in the strain.

Figure 8 presents cell dimension changes for the $\mathrm{Ce}_{1-x} \mathrm{~Tb}_{x} \mathrm{O}_{y}$ samples as a function of temperature. In general, the cell dimensions increased with an elevation of the temperature. Two different slopes were observed with the break point at around $600{ }^{\circ} \mathrm{C}$. The different slopes imply that the change in cell dimension was not only a consequence of thermal expansion, but was also affected by the sintering process. Variations of the strain magnitude are expected to affect this process. ${ }^{42}$ The net result is a smaller slope at temperatures lower than $600{ }^{\circ} \mathrm{C}$ and a bigger one at higher temperatures. The slope below $600{ }^{\circ} \mathrm{C}$ is consistent with a thermal dilation coefficient of $\sim 6.3 \times 10^{-5} \AA \mathrm{K}^{-1}$ reported for ceria systems and summarized in the review by Trovarelli. ${ }^{53}$

Table III lists cell dimensions, particle sizes, and strain parameters obtained by XRD analysis after heating the $\mathrm{Ce}_{1-x} \mathrm{~Tb}_{x} \mathrm{O}_{y}$ samples to $925^{\circ} \mathrm{C}$ and subsequent cooling to room temperature. A comparison with the corresponding results in Table I indicates that sintering at high temperature induces a minor effect on the cell dimensions, but causes a large increase in the particle size and a reduction in the lattice strain. $\mathrm{Tb} L_{\mathrm{III}}$-edge XANES spectra for $\mathrm{Ce}_{1-x} \mathrm{~Tb}_{x} \mathrm{O}_{y}$

TABLE III. Structural parameters for $\mathrm{Ce}_{1-x} \mathrm{~Tb}_{x} \mathrm{O}_{y}$ nanoparticles after sintering ${ }^{\mathrm{a}}$.

\begin{tabular}{cccc}
\hline \hline Ce/Tb ratio & $\begin{array}{c}\text { Cell } \\
\text { dimensions }(\AA)\end{array}$ & $\begin{array}{c}\text { Particle sizes } \\
(\mathrm{nm})\end{array}$ & $\begin{array}{c}\text { Strain } \\
(\text { a.u. })\end{array}$ \\
\hline $1 / 0$ & 5.41 & 22.5 & 0.08 \\
$9 / 1$ & 5.39 & 15.4 & 0.26 \\
$2 / 1$ & 5.37 & 13.6 & 0.34 \\
$1 / 1$ & 5.35 & 12.1 & 0.55 \\
\hline \hline
\end{tabular}

aThe samples were heated to $925^{\circ} \mathrm{C}$ and then cooled to room temperature. 


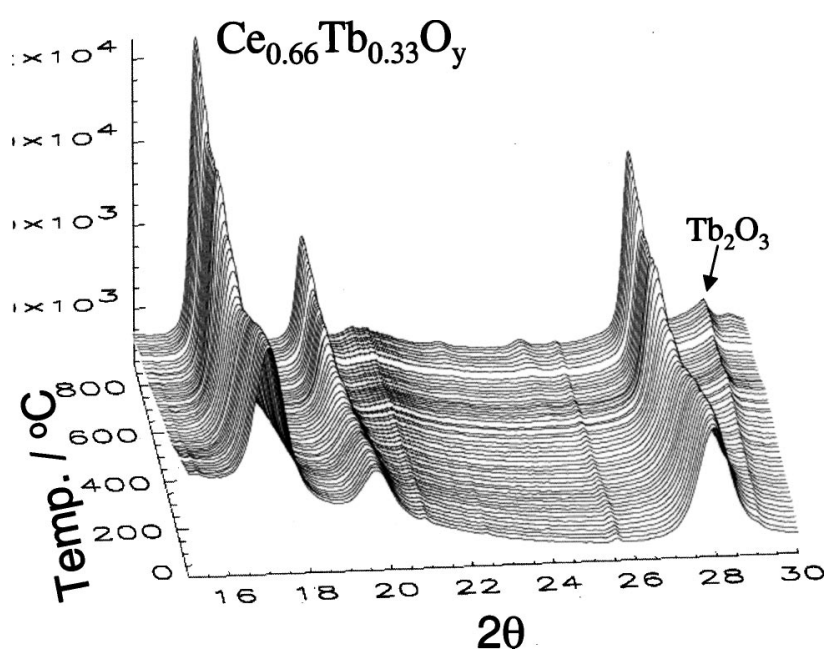

FIG. 9. Temperature-resolved $\mathrm{x}$-ray diffraction patterns for the reaction of $\mathrm{Ce}_{0.66} \mathrm{~Tb}_{0.33} \mathrm{O}_{2}$ with $\mathrm{H}_{2}$ (Heating ramp $=4.8^{\circ} \mathrm{C} / \mathrm{min} ; \lambda=0.92007 \AA$ A.). $\mathrm{Tb}_{2} \mathrm{O}_{3}$ is probably formed in the reduction process.

samples that were heated to $925^{\circ} \mathrm{C}$ and then cooled to $25^{\circ} \mathrm{C}$ showed line shapes very similar to those seen in Fig. 6. Thus, the heating and cooling treatment had a minor effect on the relative concentration of $\mathrm{Tb}^{3+}$ in the $\mathrm{Ce}_{1-x} \mathrm{~Tb}_{x} \mathrm{O}_{y}$ nanoparticles.

\section{Reaction of $\mathrm{Ce}_{1-x} \mathrm{~Tb}_{x} \mathrm{O}_{y}$ nanoparticles with $\mathrm{H}_{2}$}

The chemical behavior of the $\mathrm{Ce}_{1-x} \mathrm{~Tb}_{x} \mathrm{O}_{y}$ nanoparticles listed in Table I is particularly interesting due to their large content of defects (as reflected in the strain parameter) and $\mathrm{O}$ vacancies. We investigated their reactivity towards hydrogen in temperature-programmed reduction experiments. Many oxide catalysts are activated by partial reduction, ${ }^{54}$ and the reaction with $\mathrm{H}_{2}$ is sensitive to the existence of defects in the oxide lattice. ${ }^{55}$ Metal cations located near defects in an oxide surface are efficient for the adsorption and dissociation of $\mathrm{H}_{2}$ (the first step in the reduction process of an oxide). ${ }^{55} \mathrm{~A}$ temperature-resolved XRD pattern for $\mathrm{Ce}_{0.66} \mathrm{~Tb}_{0.33} \mathrm{O}_{y}$ is displayed in Fig. 9, showing the diffraction line changes during heating of the sample from $25^{\circ} \mathrm{C}$ to $900{ }^{\circ} \mathrm{C}$ under a $5 \%$ $\mathrm{H}_{2} / \mathrm{He}$ flow. Comparing to similar results for annealing in air (for example, see Fig. 2), phase separations and changes are evident in the diffraction patterns of Fig. 9. The extra diffraction features point to the formation of a phase like $\mathrm{Tb}_{2} \mathrm{O}_{3}$ (Ref. 56) during the reduction process. The ability of bulk cerium/terbium mixed oxides to reduce under inert gas, even at mild temperature, has been reported previously. ${ }^{4}$ In such conditions, the mixed oxides release oxygen molecules and the generation of vacancies and reduction from tetravalent to trivalent cations occurs. ${ }^{4}$ Thus, it is not strange that the transformation of $\mathrm{Tb}^{4+} / \mathrm{Ce}^{4+}$ to $\mathrm{Tb}^{3+} / \mathrm{Ce}^{3+}$ occurs in the $\mathrm{Ce}_{1-x} \mathrm{~Tb}_{x} \mathrm{O}_{y}$ nanoparticles. Furthermore, structural differences between our fluorite-type samples and $\mathrm{Tb}_{2} \mathrm{O}_{3} / \mathrm{Ce}_{2} \mathrm{O}_{3}$ (Ref. 56) could induce the phase separation seen in Fig. 9.

Figure 10 displays changes in cell dimension upon the heating of $\mathrm{Ce}_{1-x} \mathrm{~Tb}_{x} \mathrm{O}_{y}$ nanoparticles from 25 to $900^{\circ} \mathrm{C}$. We can separate these data in three ranges or sections: range I from 25 to $200{ }^{\circ} \mathrm{C}$ (where the reduction rate is rather slow

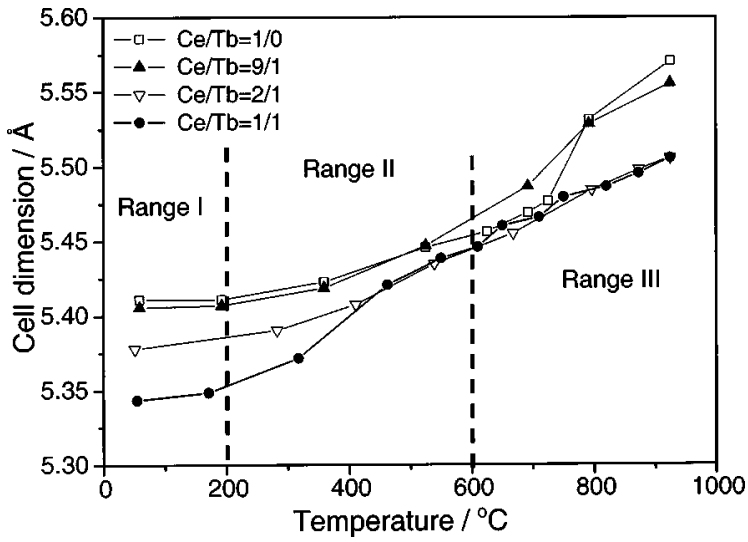

FIG. 10. Variations in cell dimension observed during the temperature programmed reduction of the $\mathrm{Ce}_{1-x} \mathrm{~Tb}_{x} \mathrm{O}_{y}$ nanoparticles in hydrogen (Heating ramp $=4.8^{\circ} \mathrm{C} / \mathrm{min}$ ).

and there are very minor changes in cell dimension), range II from 200 to $600^{\circ} \mathrm{C}$ (where the reduction rate becomes faster), and range III from 600 to $900{ }^{\circ} \mathrm{C}$ (where substantial sintering of the nanoparticles is simultaneously occurring, see Fig. 7). The produced $\mathrm{Tb}^{3+} / \mathrm{Ce}^{3+}$ cations during reduction led to a unit cell expansion because of their larger ionic radii compared to $\mathrm{Tb}^{4+} / \mathrm{Ce}^{4+}$ cations. ${ }^{4,18}$ In addition, there could have been a minor lattice expansion due to the embedding of hydrogen into the lattice of the oxide. ${ }^{18}$ The temperature ranges I and II in Fig. 10 are particularly interesting because below $600{ }^{\circ} \mathrm{C}$ no big changes occur in the morphological properties of the nanoparticles. One can see that the systems with the larger strain and content of $\mathrm{O}$ vacancies, $\mathrm{Ce}_{0.66} \mathrm{~Tb}_{0.33} \mathrm{O}_{y}$ and $\mathrm{Ce}_{0.5} \mathrm{~Tb}_{0.5} \mathrm{O}_{y}$, interact stronger with hydrogen and exhibit a substantial increase in the cell dimensions. The pure $\mathrm{CeO}_{2}$ and $\mathrm{Ce}_{0.9} \mathrm{~Tb}_{0.1} \mathrm{O}_{y}$ undergo significant reduction only at temperatures above $600^{\circ} \mathrm{C}$. In $\mathrm{Ce}_{0.9} \mathrm{~Tb}_{0.1} \mathrm{O}_{y}$ the $\mathrm{Tb}^{3+} / \mathrm{Tb}^{4+}$ ratio is much larger than in $\mathrm{Ce}_{0.5} \mathrm{~Tb}_{0.5} \mathrm{O}_{y}$ (see Fig. 6), but the large concentration of lattice defects in $\mathrm{Ce}_{0.5} \mathrm{~Tb}_{0.5} \mathrm{O}_{y}$ makes this system most reactive towards $\mathrm{H}_{2}$. The $\mathrm{O}$ vacancies and structural defects that favor the reaction of $\mathrm{Ce}_{0.66} \mathrm{~Tb}_{0.33} \mathrm{O}_{y}$ and $\mathrm{Ce}_{0.5} \mathrm{~Tb}_{0.5} \mathrm{O}_{y}$ with hydrogen also should favor the cleavage of $\mathrm{N}-\mathrm{O}$ and $\mathrm{S}-\mathrm{O}$ bonds in $\mathrm{DeNO}_{x}$ and $\mathrm{DeSO}_{x}$ processes. ${ }^{14,57}$ Indeed, recent studies in our laboratories indicate that $\mathrm{Ce}_{0.5} \mathrm{~Tb}_{0.5} \mathrm{O}_{y}$ nanoparticles are more active for the decomposition of $\mathrm{NO}$ and $\mathrm{SO}_{2}$ than nanoparticles of $\mathrm{CeO}_{2}$ or $\mathrm{TbO}_{1.7} \cdot{ }^{58}$

\section{E. Comparison with $\mathrm{Ce}_{1-x} \mathrm{Zr}_{x} \mathrm{O}_{y}$ and $\mathrm{Ce}_{1-x} \mathrm{Ca}_{x} \mathrm{O}_{y}$ nanoparticles}

A series of structural properties for nanoparticles of $\mathrm{CeO}_{2}, \mathrm{Ce}_{0.66} \mathrm{Zr}_{0.33} \mathrm{O}_{y}, \mathrm{Ce}_{0.66} \mathrm{Ca}_{0.33} \mathrm{O}_{y}$, and $\mathrm{Ce}_{0.66} \mathrm{~Tb}_{0.33} \mathrm{O}_{y}$, are compared in Figs. 11 and 12. All the systems were heated in air from 25 to $925^{\circ} \mathrm{C}$. The data for $\mathrm{Ce}_{0.66} \mathrm{Ca}_{0.33} \mathrm{O}_{y}$ have been taken from Ref. 19. In the case of $\mathrm{Ce}_{0.66} \mathrm{Zr}_{0.33} \mathrm{O}_{y}$, data for a limited number of temperatures have been published in Ref. 18, but the corresponding new set in Figs. 11 and 12 is more extensive and the analysis of the XRD patterns was done following a more sophisticated approach (see Sec. II B). In the top panel of Fig. 11, the particle sizes of the $\mathrm{Ce}_{1-x} M_{x} \mathrm{O}_{y}(M=\mathrm{Tb}, \mathrm{Zr}$, or $\mathrm{Ca})$ systems were smaller than 

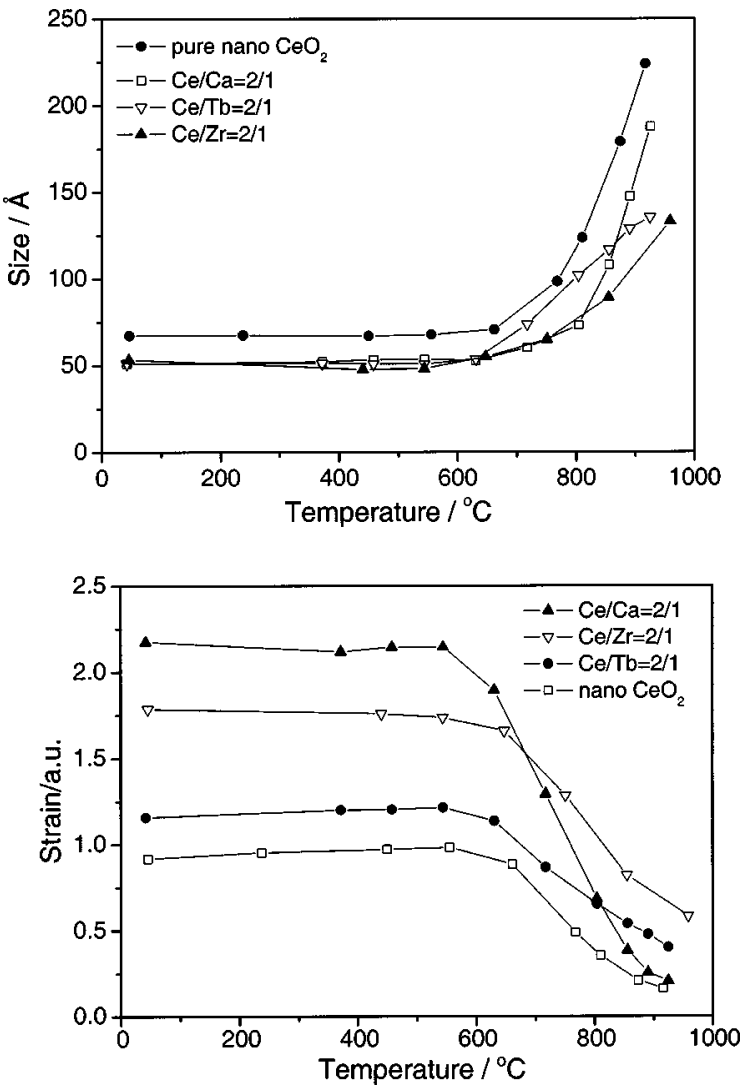

FIG. 11. Effects of temperature on the particle size (top panel) and lattice strain (bottom panel) of a series of $\mathrm{Ce}_{0.66} M_{0.33} \mathrm{O}_{y}$ nanoparticles $(M=\mathrm{Tb}, \mathrm{Zr}$, or $\mathrm{Ca}$ ). For comparison, the results for nanoparticles of pure $\mathrm{CeO}_{2}$ are also included.

those of the pure ceria, and were all almost the same at temperatures below $600^{\circ} \mathrm{C}$. All the samples started to agglomerate once the temperatures were higher than $600^{\circ} \mathrm{C}$ (Fig. 11). However, the agglomeration rate determined from the slope increased in the order of $\mathrm{Ce}_{0.66} \mathrm{Zr}_{0.33} \mathrm{O}_{y}$ $<\mathrm{Ce}_{0.66} \mathrm{~Tb}_{0.33} \mathrm{O}_{y}<\mathrm{Ce}_{0.66} \mathrm{Ca}_{0.33} \mathrm{O}_{y} \approx$ nano ceria. This indicates that both $\mathrm{Tb}$ and $\mathrm{Zr}$ cations improved the morphological stability of the doped ceria nanoparticles, while Ca cations did not. In the bottom panel of Fig. 11, one can see that $\mathrm{Ca}$

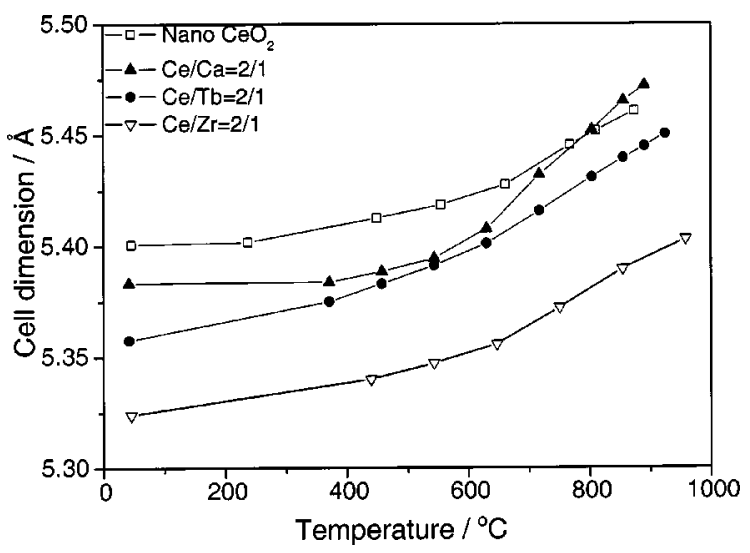

FIG. 12. Cell dimensions, as a function of temperature, for nanoparticles of $\mathrm{CeO}_{2}$ and $\mathrm{Ce}_{0.66} M_{0.33} \mathrm{O}_{y}(M=\mathrm{Tb}, \mathrm{Zr}$, or $\mathrm{Ca})$. induces the largest strain in the ceria lattice. In fact, the strain in the $\mathrm{Ce}_{1-x} \mathrm{Ca}_{x} \mathrm{O}_{y}$ nanoparticles is such that $\mathrm{CaO}$ segregates at temperatures above $700{ }^{\circ} \mathrm{C}$. ${ }^{19}$

At room temperature, the cell dimensions of all the $\mathrm{Ce}_{1-x} \mathrm{M}_{x} \mathrm{O}_{y}$ nanoparticles were smaller than those of the pure ceria nanoparticles (see Fig. 12). Interestingly, the magnitude of the contraction followed almost the reverse order as the sintering stability: $\mathrm{Ce}_{0.66} \mathrm{Zr}_{0.33} \mathrm{O}_{y}>\mathrm{Ce}_{0.66} \mathrm{~Tb}_{0.33} \mathrm{O}_{y}$ $>\mathrm{Ce}_{0.66} \mathrm{Ca}_{0.33} \mathrm{O}_{y}>$ nano ceria. From the data described above, it appears that the sintering properties for the $\mathrm{Ce}_{1-x} \mathrm{M}_{x} \mathrm{O}_{y}$ nanoparticles depend, to a first approximation, on the ionic radius of the second metal $(M)$ and its bond distance with oxygen. Thus, in $\mathrm{ZrO}_{2}$, a smaller $\mathrm{Zr}^{4+}$ ionic radius $(0.80 \AA)$ and a shorter $\mathrm{Zr}-\mathrm{O}$ bond distance (in monoclinic structure: around $2.22 \AA$; in cubic structure: $2.195 \AA$ ) compared to $\mathrm{CeO}_{2}\left(\mathrm{Ce}^{4+}\right.$ ionic radius: $0.97 \AA$, and $\mathrm{Ce}-\mathrm{O}$ bond distance: $2.345 \AA$ ) resulted in forming a more close packed array of atoms in the unit cell in the $\mathrm{Ce}_{1-x} \mathrm{Zr}_{x} \mathrm{O}_{y}$ nanoparticles, hence the morphological stability was increased, and enhanced with the increase of $\mathrm{Zr}$ concentration. ${ }^{18}$ On the other hand, $\mathrm{CaO}$ with a larger $\mathrm{Ca}^{2+}$ ionic radius $(0.99 \AA)$ and a longer $\mathrm{Ca}-\mathrm{O}$ bond distance $(2.405$ $\AA$ ) did not increase the morphological stability of the cerium oxide. The $\mathrm{Tb}^{4+}$ ionic radius $(0.88 \AA)$ and the $\mathrm{Tb}-\mathrm{O}$ bond distance (around $2.3 \AA$ or higher) of the terbium oxide fall in between those cited above, and $\mathrm{Tb}$ had an intermediate influence on the cerium oxide. Another problem with $\mathrm{Ca}$ in $\mathrm{Ce}_{1-x} \mathrm{Ca}_{x} \mathrm{O}_{y}$ is its different charge (see Table II) and its tendency to form oxides that prefer a rock-salt crystal structure. ${ }^{19}$

Oxygen occupancies were determined with XRD data from the Advanced Photon Source by the Rietveld method. Full oxygen occupancy for the $\mathrm{Ce}_{0.66} \mathrm{Zr}_{0.33} \mathrm{O}_{y}$ sample indicated that there were no ordered oxygen vacancies in this sample, while the $\mathrm{Ce}_{0.66} \mathrm{Ca}_{0.33} \mathrm{O}_{y}$ sample had a large amount of oxygen vacancies with a refined oxygen occupancy value of 0.86 . The oxygen occupancy in the $\mathrm{Ce}_{0.66} \mathrm{~Tb}_{0.33} \mathrm{O}_{y}$ sample was 0.92 . This trend in oxygen occupancies is consistent with the $\mathrm{Tb}, \mathrm{Zr}$, and $\mathrm{Ca}$ oxidation states found with XANES in this study and in previous works. ${ }^{18,19}$ Therefore, Ca mixing introduced the maximum amount of lattice defects (particularly oxygen vacancies) into the ceria nanoparticles, but the oxide compound stability at high temperature was degraded as described above. The introduction of $\mathrm{Tb}$ leads to nanoparticles with a good thermal stability and a significant content of $\mathrm{O}$ vacancies which can affect chemical reactions. ${ }^{14,57}$ The combination of both properties makes $\mathrm{Ce}_{1-x} \mathrm{~Tb}_{x} \mathrm{O}_{y}$ nanoparticles special.

\section{CONCLUSIONS}

Density functional calculations and Raman spectra point to a small tetragonal distortion after introducing terbium in ceria. In bulk $\mathrm{Ce}_{1-x} \mathrm{~Tb}_{x} \mathrm{O}_{2}$ and in $\mathrm{Ce}_{1-x} \mathrm{~Tb}_{x} \mathrm{O}_{y}$ nanoparticles $(x \leqslant 0.5)$, there is a small contraction $(\leqslant 0.08 \AA)$ in the cell dimensions with respect to pure $\mathrm{CeO}_{2}$. The presence of $\mathrm{Tb}$ generates strain in the lattice through the creation of crystal imperfections and $\mathrm{O}$ vacancies. The strain increases with the 
content of $\mathrm{Tb}$ and affects the chemical reactivity of the $\mathrm{Ce}_{1-x} \mathrm{~Tb}_{x} \mathrm{O}_{y}$ nanoparticles towards $\mathrm{H}_{2}$. $\mathrm{Tb}_{2} \mathrm{O}_{3}$ is formed during the reduction in hydrogen.

DF calculations for bulk $\mathrm{Ce}_{1-x} \mathrm{~Tb}_{x} \mathrm{O}_{2}$ and $\mathrm{Ce}_{8-n} \mathrm{~Tb}_{n} \mathrm{O}_{16}$ $(n=0,1,2$, or 4$)$ clusters show oxide systems that are not fully ionic. The theoretical results and XANES spectra indicate that neither a $\mathrm{Ce} \leftrightarrow \mathrm{Tb}$ exchange nor the introduction of oxygen vacancies in $\mathrm{Ce}_{1-x} \mathrm{~Tb}_{x} \mathrm{O}_{y}$ significantly affect the charge on the Ce cations. On the other hand, the $\mathrm{O} K$-edge and $\mathrm{Tb} L_{\mathrm{III}}$-edge XANES spectra of $\mathrm{Ce}_{1-x} \mathrm{~Tb}_{x} \mathrm{O}_{y}$ nanoparticles show substantial changes with respect to the corresponding spectra of $\mathrm{CeO}_{2}$ and $\mathrm{TbO}_{1.7}$. The $\mathrm{Ce}_{0.5} \mathrm{~Tb}_{0.5} \mathrm{O}_{y}$ compounds exhibit a much larger $\mathrm{Tb}^{3+} / \mathrm{Tb}^{4+}$ ratio than $\mathrm{TbO}_{1.7}$.

A comparison with the properties of $\mathrm{Ce}_{1-x} \mathrm{Zr}_{x} \mathrm{O}_{y}$ and $\mathrm{Ce}_{1-x} \mathrm{Ca}_{x} \mathrm{O}_{y}$ shows that $\mathrm{Tb}$ induces structural and electronic perturbations in ceria quite different from those found after mixing with $\mathrm{Zr}$ and $\mathrm{Ca}$. The $\mathrm{Ce}_{1-x} \mathrm{Zr}_{x} \mathrm{O}_{y}$ nanoparticles have the best stability against sintering, but a negligible content of $\mathrm{O}$ vacancies. Mixing with $\mathrm{Ca}$ introduces a substantial amount of $\mathrm{O}$ vacancies, but phase segregation occurs at temperatures close to $700^{\circ} \mathrm{C}$. In this respect, the $\mathrm{Ce}_{1-x} \mathrm{~Tb}_{x} \mathrm{O}_{y}$ systems combine stability at high temperature and a significant concentration of $\mathrm{O}$ vacancies, making them attractive for chemical and catalytic applications.

\section{ACKNOWLEDGMENTS}

The authors would like to thank P. J. Lee (APS, Argonne National Laboratory) and P. J. Chupas (SUNY Stony Brook) for their help with the experiments carried at the APS, Argonne National Laboratory. The research carried out at the Chemistry Department of Brookhaven National Laboratory was financed through Contract No. DE-AC02-98CH10086 with the U.S. Department of Energy (Division of Chemical Sciences). The NSLS and APS are supported by the Divisions of Materials and Chemical Sciences of DOE. Work at the "Instituto de Catálisis (CSIC)" was done with financial support from CICYT (Contract No. MAT2000-1467).

${ }^{1}$ J. M. Thomas and W. J. Thomas, Principles and Practice of Heterogeneous Catalysis (VCH, New York, 1997); A. V. Slack and G. A. Holliden, Sulfur Dioxide Removal from Waste Gases, 2nd ed. (Noyes Data Corporation, Park Ridge, NJ, 1975); A. Pieplu, O. Saur, J.-C. Lavalley, O. Legendre, and C. Nedez, Catal. Rev. - Sci. Eng. 40, 409 (1998).

${ }^{2}$ Catalysis by Ceria and Related Materials, edited by A. Trovarelli (Imperial College Press, London, 2002).

${ }^{3}$ K. Almusaiteer, R. Krishnamurthy, and S. S. C. Chuang, Catal. Today $\mathbf{5 5}$, 291 (2000)

${ }^{4}$ A. Trovarelli, M. Boaro, E. Rocchini, C. de Leitenburg, and G. Dolcetti, J. Alloys Compd. 323-324, 584 (2001).

${ }^{5}$ J. Kašpar, P. Fornasiero, and M. Graziani, Catal. Today 50, 285 (1999).

${ }^{6}$ S. O. Yao, H. Morikawa, N. Izu, and K. Okuda, J. Jpn. Inst. Met. 59, 1237 (1995).

${ }^{7}$ A. Trovarelli, Comments Inorg. Chem. 20, 263 (1999).

${ }^{8}$ S. Bernal, G. Blanco, M. A. Cauqui, P. Corchado, J. M. Pintado, and J. M. Rodríguez-Izquierdo, Chem. Commun. (Cambridge), 1545 (1997).

${ }^{9}$ S. Bernal, G. Blanco, J. J. Delgado, J. M. Pintado, and J. M. RodriguezIzquierdo, J. Alloys Compd. 344, 347 (2002).

${ }^{10}$ A. Trovarelli, Catal. Rev. - Sci. Eng. 38, 439 (1996); G. Blanco, J. M. Pintado, S. Bernal et al., Surf. Interface Anal. 34, 120 (2002).

${ }^{11}$ (a) M. Fernández-García, A. Martínez-Arias, J. C. Hanson, and J. A. Rodriguez, Chem. Rev. (in press); (b) M. Fernández-García, Catal. Rev. 44, 59 (2002); (c) J. G. Chen, Surf. Sci. Rep. 30, 1 (1997).

${ }^{12}$ J. A. Rodriguez, Catal. Today 85, 177 (2003).
${ }^{13}$ P. Nachimuthu, W. C. Shih, R. S. Liu, L. Y. Jang, and J. M. Chen, J. Solid State Chem. 149, 408 (2000); L. A. J. Garvie and P. R. Buseck, J. Phys. Chem. Solids 60, 1943 (1999); F. Zhang, S.-W. Chan, J. E. Spanier, E. Apak, Q. Jin, R. D. Robinson, and I. P. Herman, Appl. Phys. Lett. 80, 127 (2002).

${ }^{14}$ (a) G. Liu, J. A. Rodriguez, J. Hrbek, J. Dvorak, and C. H. F. Peden, J. Phys. Chem. B 105, 7762 (2001); (b) G. Liu, J. A. Rodriguez, Z. Chang, J. Hrbek, and C. H. F. Peden, ibid. 108, 2931 (2004); (c) S. H. Overbury and D. R. Mullins, Catalysis by Ceria and Related Materials (Ref. 2) Chap. 9; (d) J. A. Rodriguez, X. Wang, G. Liu, J. Hanson, J. Hrbek, C. H. F. Peden, A. Iglesias-Juez, and M. Fernández-García, J. Mol. Catal. A (in press).

${ }^{15}$ (a) C.-K. Loong and M. Ozawa, Catal. Today 50, 329 (1999); (b) T. L. Zhu, L. Kundakovic, A. Dreher, M. Flytzani-Stephanopoulos, ibid. 50, 381 (1999); (c) Q. Fu, H. Saltsburg, and M. Flytzani-Stephanopoulos, Science 301, 935 (2003); (d) S. D. Park, J. M. Vohs, and R. J. Gorte, Nature (London) 404, 265 (2000); (d) G. Pacchioni, J. M. Ricart, and F. Illas, J. Am. Chem. Soc. 116, 10152 (1994).

${ }^{16}$ J. R. McBride, K. C. Hass, B. D. Poindexter, and W. H. Weber, J. Appl. Phys. 76, 2435 (1994).

${ }^{17}$ P. Fornasiero, G. Balducci, R. Di Monte, J. Kašpar, V. Sergo, G. Gubitosa, A. Ferrero, and M. Graziani, J. Catal. 164, 173 (1996).

${ }^{18}$ J. A. Rodriguez, J. C. Hanson, J.-Y. Kim, G. Liu, A. Iglesias-Juez, and M. Fernández-García, J. Phys. Chem. B 107, 3535 (2003).

${ }^{19}$ J. A. Rodriguez, X. Wang, J. C. Hanson, G. Liu, A. Iglesias-Juez, and M. Fernández-García, J. Chem. Phys. 119, 5659 (2003).

${ }^{20}$ Z. C. Kang and L. Eyring, J. Alloys Compd. 181, 483 (1992).

${ }^{21}$ M. Boaro, M. Vicario, C. de Leitenburg, G. Dolcetti, and A. Trovarelli, Catal. Today 77, 407 (2003).

${ }^{22}$ G. Blanco, J. J. Calvino, M. A. Cauqui, P. Corchado, C. Lopez-Cartes, and J. A. Perez-Omil, Electron Microscopy and Analysis 1999, Institute of Physics Conference Series (Institute of Physics, Bristol, UK, 1999), Vol. 161, p. 541.

${ }^{23}$ G. Blanco, J. J. Calvino, M. A. Cauqui, P. Corchado, C. Lopez-Cartes, C. Colliex, J. A. Perez-Omil, and O. Stephan, Chem. Mater. 11, 3610 (1999).

${ }^{24}$ S. Bernal, G. Blanco, M. A. Cauqui, M. P. Corchado, C. Larese, J. M. Pintado, and J. M. Rodríguez-Izquierdo, Catal. Today 53, 607 (1999).

${ }^{25}$ A. Martínez-Arias, M. Fernández-García, V. Ballesteros, L. N. Salamanca, J. C. Conesa, C. Otero, and J. Soria, Langmuir 50, 261 (1999).

${ }^{26}$ M. Fernández-García, A. Martínez-Arias, A. B. Hungría, A. Iglesias-Juez, J. C. Conesa, and J. Soria, Phys. Chem. Chem. Phys. 80, 127 (2002).

${ }^{27}$ P. Norby and J. C. Hanson, Catal. Today 43, 301 (1998).

${ }^{28}$ P. J. Chupas, M. F. Ciraolo, J. C. Hanson, and C. P. Grey, J. Am. Chem. Soc. 123, 1694 (2001).

${ }^{29}$ (a) Reflex package provided by Accelrys; (b) G. S. Pawley, J. Appl. Crystallogr. 14, 357 (1981); (c) P. Thompson, D. E. Cox, and J. B. Hastings, J. Appl. Crystallogr. 20, 79 (1987); (d) J. Baldinozzi and J. F. Berar, ibid. 26, 128 (1993); (e) P. Scherrer, Gott. Nachr. 2, 98 (1918).

${ }^{30}$ A. P. Hammersely, S. O. Svensson, and A. Thompson, Nucl. Instrum. Methods Phys. Res. 346, 321 (1994).

${ }^{31}$ A. C. Larson and R. B. von Dreele, GSAS General Structure Analysis System. Report LAUR 86-748; Los Alamos National Laboratory: Los Alamos, NM, 1995; A. M. Reitveld, J. Appl. Crystallogr. 2, 65 (1969); The cell dimensions obtained taking into consideration asymmetry effects are a little bit different $(0.01-0.02 \AA)$ from those obtained ignoring asymmetry. Independently of this, variations of the same order in the lattice dimension can be expected depending on the exact experimental procedure used for the preparation of the nanoparticles.

${ }^{32}$ (a) M. C. Payne, D. C. Allan, T. A. Arias, and J. D. Johannopoulus, Rev. Mod. Phys. 64, 1045 (1992); (b) V. Milman, J. A. Winkler, J. A. White, C. J. Pickard, M. C. Payne, E. V. Akhmatskaya, and R. H. Nobes, Int. J. Quantum Chem. 77, 895 (2000).

${ }^{33}$ J. A. Rodriguez, Theor. Chem. Acc. 107, 117 (2002).

${ }^{34}$ D. Vanderbilt, Phys. Rev. B 41, 7892 (1990).

${ }^{35}$ H. J. Monkhorst and J. D. Pack, Phys. Rev. B 13, 5188 (1976).

${ }^{36}$ J. P. Perdew, K. Burke, and M. Ernzerhof, Phys. Rev. Lett. 77, 3865 (1996).

${ }^{37}$ M. D. Segall, C. J. Pickard, R. Shah, and M. C. Payne, Phys. Rev. B 54, 16317 (1996); M. D. Segall, C. J. Pickard, R. Shah, and M. C. Payne, Mol. Phys. 89, 571 (1996).

${ }^{38}$ A. Szabo and N. S. Ostlund, Modern Quantum Chemistry (McGraw-Hill, New York, 1989); K. B. Wiberg and P. R. Rablen, J. Comput. Chem. 14, 1504 (1993).

${ }^{39}$ C. Kittel, Introduction to Solid State Physics, 6th ed. (Wiley, New York, 1986), p. 76. 
${ }^{40}$ D. M. Gruen, W. C. Koehler, and J. J. Katz, J. Am. Chem. Soc. 73, 1475 (1951).

${ }^{41}$ J. E. Spanier, R. D. Robinson, F. Zhang, S.-W. Chan, and I. P. Herman, Phys. Rev. B 64, 245407 (2001).

${ }^{42}$ R. Jenkins and R. L. Snyder, Introduction to X-ray Powder Diffractometry (Wiley, New York, 1996), p. 91.

${ }^{43}$ (a) A. Fujimori, Phys. Rev. B 28, 2281 (1983); (b) E. Wuillioud, B. Delley, W.-D. Schneider, and Y. Baer, Phys. Rev. Lett. 53, 202 (1984); (c) F. Marabelli and P. Wachter, Phys. Rev. B 36, 1238 (1987).

${ }^{44}$ D. D. Koelling, A. M. Boring, and J. H. Wood, Solid State Commun. 47, 227 (1983).

${ }^{45}$ T. Moeller, Inorganic Chemistry (Wiley, New York, 1982), pp. 82-83.

${ }^{46}$ Z. Y. Wu, F. Jollet, S. Gota, N. Thromat, M. Gautier-Soyer, and T. Petit, J. Phys.: Condens. Matter 11, 7185 (1999).

${ }^{47}$ D. R. Mullins, S. H. Overbury, and D. R. Huntley, Surf. Sci. 409, 307 (1998).

${ }^{48}$ Z. Hu, R. Meier, C. Schubler-Langeheine et al., Phys. Rev. B 60, 1460 (1999).

${ }^{49}$ L. Douillard, M. Gautier, N. Thromat, M. Henriot, and M. J. Guittet, Phys. Rev. B 49, 16171 (1994).

${ }^{50}$ R. C. Karnatak, J. Alloys Compd. 192, 64 (1993).

${ }^{51}$ R. D. Shannon and C. T. Prewitt, Acta Crystallogr., Sect. B: Struct. Sci. B25, 925 (1969)
${ }^{52}$ A. B. Hungría, A. Martínez-Arias, M. Fernández-García, A. Iglesias-Juez, A. Guerrero-Ruiz, J. J. Calvino, J. C. Conesa, and J. Soria, Chem. Mater. 15, 4309 (2003).

${ }^{53}$ A. Trovarelli, Catalysis by Ceria and Related Materials (Ref. 2), Chap. 2.

${ }^{54}$ (a) H. H. Kung, Transition Metal Oxides: Surface Chemistry and Catalysis (Elsevier, New York, 1989); (b) L. Kundakovic and M. FlytzaniStephanopoulos, J. Catal. 179, 203 (1998); (c) T. Zhu, L. Kundakovic, A. Dreher, and M. Flytzani-Stephanopoulos, Catal. Today 50, 381 (1999).

55 (a) J. A. Rodriguez, J. C. Hanson, A. I. Frenkel, J. Y. Kim, and M. Pérez, J. Am. Chem. Soc. 124, 346 (2002); (b) J. Y. Kim, J. A. Rodriguez, J. C. Hanson, A. I. Frenkel, and P. L. Lee, ibid. 125, 10684 (2003).

${ }^{56}$ A. Saiki, N. Ishizawa, N. Mizutani, and M. Kato, J. Ceram. Soc. Jpn. 93, 649 (1985).

${ }^{57}$ (a) S. H. Overbury, D. R. Mullins, D. Huntley, and L. Kundakovic, J. Catal. 186, 296 (1999); (b) J. Stubenrauch and J. M. Vohs, ibid. 159, 50 (1996); (c) J. A. Rodriguez, T. Jirsak, A. Freitag, J. C. Hanson, J. Z. Larese, and S. Chaturvedi, Catal. Lett. 62, 113 (1999); (d) R. M. Ferrizz, R. J. Gorte, and J. M. Vohs, ibid. 82, 123 (2002).

${ }^{58}$ J. A. Rodriguez, X. Wang, J. C. Hanson, A. Iglesias-Juez, and M. Fernández-García (to be published). 